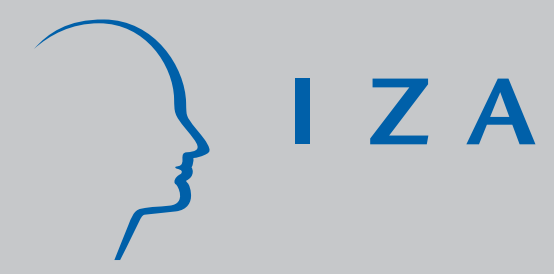

IZA DP No. 1920

Work Experience as a Source of Specification Error in Earnings Models: Implications for Gender Wage Decompositions

Tracy L. Regan

Ronald L. Oaxaca

J anuary 2006 


\title{
Work Experience as a Source of Specification Error in Earnings Models: Implications for Gender Wage Decompositions
}

\author{
Tracy L. Regan \\ University of Miami \\ Ronald L. Oaxaca \\ University of Arizona \\ and IZA Bonn \\ Discussion Paper No. 1920 \\ January 2006 \\ IZA \\ P.O. Box 7240 \\ 53072 Bonn \\ Germany \\ Phone: +49-228-3894-0 \\ Fax: +49-228-3894-180 \\ Email: iza@iza.org
}

\begin{abstract}
Any opinions expressed here are those of the author(s) and not those of the institute. Research disseminated by IZA may include views on policy, but the institute itself takes no institutional policy positions.

The Institute for the Study of Labor (IZA) in Bonn is a local and virtual international research center and a place of communication between science, politics and business. IZA is an independent nonprofit company supported by Deutsche Post World Net. The center is associated with the University of Bonn and offers a stimulating research environment through its research networks, research support, and visitors and doctoral programs. IZA engages in (i) original and internationally competitive research in all fields of labor economics, (ii) development of policy concepts, and (iii) dissemination of research results and concepts to the interested public.
\end{abstract}

IZA Discussion Papers often represent preliminary work and are circulated to encourage discussion. Citation of such a paper should account for its provisional character. A revised version may be available directly from the author. 
IZA Discussion Paper No. 1920

January 2006

\section{ABSTRACT \\ Work Experience as a Source of Specification Error in Earnings Models: Implications for Gender Wage Decompositions*}

We address the bias from using potential vs. actual experience in earnings models. Statistical tests reject the classical errors-in-variable framework. The nature of the measurement error is best viewed as a model misspecification problem. We correct for this by modeling actual experience as a stochastic regressor and predicting experience using the NLSY79 and the PSID. Predicted experience measures are applied to the IPUMS. Our results suggest that potential experience biases the effects of schooling and the rates of return to labor market experience. Using such a measure in earnings models underestimates the explained portion of the male-female wage gap.

JEL Classification: $\quad$ C81, J24, J31

Keywords: experience, specification error, decomposition, gender

Corresponding author:

Ronald L. Oaxaca

Department of Economics

University of Arizona

P.O. Box 210108

Tucson, AZ 85721-0108

USA

Email: rlo@email.arizona.edu

\footnotetext{
${ }^{*}$ We are grateful for comments received at the 2005 SOLE/EALE Annual Meeting, the 2005 American Economic Association Annual Meeting, the 2004 Western Economic Association International 79th Annual Conference in Vancouver, Canada, and from seminar participants at the University of Aberdeen, the University of Oxford, the University of Miami, and the University of Arizona. We would also like to thank Tim Barmby and Solomon Polachek.
} 


\section{Introduction}

This paper addresses the bias inherent in the use of potential, as opposed to actual, work experience measures in human capital earnings models. At a minimum, traditional (Mincerian) log wage equations employ one's completed schooling, ability (if available), prior work experience, and its square. The latter two variables capture the concave relationship that exists between labor market experience and its pecuniary rewards. Many data sets do not contain actual work histories, however. The 1979 National Longitudinal Survey of Youth (NLSY79) and the Panel Study of Income Dynamics (PSID) are two exceptions and are thus preferable in many instances. Because of their relatively small size and unrepresentativeness, such data sets are not always desirable [Moulton (1986)]. Thus, one is often forced to proxy for actual work experience with potential work experience - measured as the time elapsed since leaving school. Such a measure assumes continuous work histories and abstracts away from employment status (over-, full-, or part-time) and multiple-job holding.

Most researchers seem content using potential work experience measures for males as it is not unreasonable to assume that they have been in the labor force continuously since leaving school. The use of such a measure for females is viewed less favorably, yet no attractive alternatives are readily apparent. In many instances, researchers confine their attention solely to males in order to avoid lapses in labor force participation that occur more often for females as they experience various life-cycle changes. While the focus on males arises from expediency, there may be no reason to exclude females from the analysis. Many researchers have undertaken great efforts to avoid the exclusion of females from their analysis (e.g., Filer, 1992; Blank, 1988; Garvey and Reimers, 1980; Corcoran, 1979; Polachek, 1975; Mincer and Polachek, 1974). The increased and more prominent role of females in the labor force warrants, if not necessitates their inclusion [Fullerton and Byrne (1976)]. While use of the Mincer proxy for work 
experience has become standard practice, we argue that the use of such a measure for males may still be problematic. Male workers, like their female counterparts, experience employment lapses. Such lapses take two different forms - namely, an active job search while unemployed or a withdrawal from the labor force. It is unreasonable to assume that one's labor market experience is affected in the same way by these two different forms of employment lapses. Furthermore, one would not expect the "return" to unemployed labor force experience to be the same as that of employed labor force experience.

This paper employs data collected from the NLSY79 and the PSID to address measurement error in work experience and to examine the implications for gender wage decompositions. The errors-in-variables framework that is usually assumed to be classical is violated here because the measurement error does not have a mean of zero and is found to be correlated with actual measures of work experience. As an alternative to viewing the problem as one of measurement error, we believe it is more fruitful to think of the problem as one of specification error. We investigate the extent to which actual experience can be predicted from other variables and extend our predicted work experience measures to a data set in which actual measures of work experience are not available - specifically, the 1990 wave of the Integrated Public Use Microdata Sample (IPUMS). The potential work experience measures tend to overstate the effects of schooling and the rates of return to labor market experience. The only exception to the latter is for the females. Our predicted work experience measures generally lead to a substantial reduction in the bias on the schooling and experience coefficients. The single exception arises from the estimated coefficient on experience squared for the NLSY79 females. Furthermore, more of the male-female wage gap is explained when our predicted work experience measures are used in lieu of potential experience.

The paper proceeds in the following fashion: Section II provides the background 
and literature review. Section III discusses the conceptual framework that underlies the analysis. Section IV discusses the data used in the analysis. Section V presents and discusses the results. Finally, Section VI concludes.

\section{Background and Literature Review}

Measurement error is a problem commonly faced in applied work. For practical purposes, measurement error in the endogenous variable is not problematic because it is usually assumed to be uncorrelated with the regressors. The $R^{2}$ of the regression is smaller, however, because of the additional noise contained in the random error term. Conversely, measurement error in regressors does pose serious problems because it leads to biased and inconsistent OLS estimates. When faced with such a problem, most researchers assume that the measurement error is classical, in the sense that the true regressors and their measurement error are uncorrelated, the random disturbance term and the measurement errors are asymptotically uncorrelated, the measurement errors are normally distributed, and that the measurement errors are uncorrelated among themselves.

The standard assumptions placed on the measurement error typically rise out of convenience and are not usually supported by empirical evidence (e.g., Black et al., 2000). Duncan and Hill (1985) and Rodgers et al. (1993) use administrative records from a large manufacturing firm to verify workers' responses to questions pertaining to earnings and hours worked while Bound and Krueger (1991) and Bound et al. (1994) examine measurement error in longitudinal earnings data. Bollinger (1998) also examines measurement error in panel data but uses a nonparametric methodology. Lee and Sepanski (1995) offer a computationally and analytically simpler method to the nonparametric methodology in consistently estimating regression models with measurement error in the dependent and/or independent variables when validation data are available. In sum, all of these validation studies confirm measurement error 
in survey data and their findings contradict many of the assumptions made in and implications drawn from classical measurement error models. ${ }^{1}$

Measurement error in other variables contained in traditional (Mincerian) log earnings regressions, specifically that of schooling, has received considerable attention in the twins-based literature. Work in this area originally stemmed from the desire to eliminate the bias due to omitted variables (e.g., ability). Ashenfelter and Krueger (1994) were also able to address measurement error in schooling through the creative use of self- and twin-reported schooling levels. While the rather large estimated rates of return to schooling seem to be an anomaly of their data set, Ashenfelter and Krueger conclude that omitted variables do not bias the rates of return to schooling upwards, as was commonly thought and subsequently reaffirmed, while measurement error in schooling biases the rates downwards. See Ashenfelter and Rouse (1998) and Rouse (1999) for follow-up work.

Flores-Lagunes and Light (2003) expand Ashenfelter and Rouse's data set of identical twins to include pairs of siblings from the NLSY79. They note that most research has assumed classical measurement error (e.g., Ashenfelter and Krueger, 1994; Ashenfelter and Rouse, 1998; Rouse, 1999) while non-classical measurement error has usually been assumed to be mean-reverting (e.g., Black et al., 2000) or "(optimal) prediction error" (e.g., Hyslop and Imbens, 2001). While Flores-Lagunes and Light consider four different measurement error constructs in investigating the causal effect of schooling on wages (none, classical, mean-reverting, and correlated person-specific), Likelihood Ratio tests support the assumption of classical measurement error. The Flores-Lagunes and Light results offer continued support of Ashenfelter and Krueger's instrumental variables strategy to correct for measurement error.

In his efforts to explain Ashenfelter and Krueger's exceptionally high within rates

\footnotetext{
${ }^{1}$ Measurement error in sensitive topics (i.e. receipt of welfare, income, alcohol use, drug use, criminal history, and embarrassing medical conditions) is examined by Marquis et al. (1986).
} 
of return to schooling, Neumark (1999) uses instrumental variables to correct for the attenuation bias due to measurement error. He concludes that the OLS rates of return to schooling may be the most accurate if the within twin ability bias is large enough to offset the measurement error bias in schooling. Like Griliches (1979), Behrman and Rosenzweig (1999) criticize the first-difference technique because such a method exacerbates the bias towards zero when measurement error exists. This is because differencing does not eliminate the measurement error in this variable, but it does, however, rid the common schooling component.

Several others researchers have abstracted away from the measurement error in schooling that is characteristic of the twins-based literature and have focused on the other explanatory variable in the traditional (Mincerian) log wage equationspecifically, work experience. The issue has been probed, mainly for females, in hopes of addressing the bias that accrues to the OLS estimates when potential work experience measures are employed instead of reported actual experience. Garvey and Reimers (1980) argue that the use of the traditional age minus schooling minus six measure is biased because people do not always complete one grade per year (either due to acceleration or retention) and that one accrues non-work time during one's life. Using the NLSY66, Garvey and Reimers instead construct predicted measures of work experience. Moulton (1986) uses Garvey and Reimers' functional form to predict work experience for an exceptionally large data set constructed from the March 1978 CPS matched with Social Security records. Filer (1992) predicts work experience using occupation-specific equations for the NLSY66 and extends his findings to the 1980 Census Public Use Microdata Tapes. Overall, these papers find marginal benefits from using predicted, as opposed to potential, work experience measures for females. 


\section{CONCEPTUAL FRAMEWORK}

As is evident from the previous discussion, much of the literature on measurement error in human capital models has focused on measurement error in a linear term (e.g., schooling). Several researchers (e.g., Ashenfelter and Rouse, 1998; Behrman and Rosenzweig, 1999) have noted the complications introduced by measurement error in a quadratic variable but few have tackled the problem. It is our intention to examine this issue more closely in the context of specification error. Note that we abstract away from any measurement errors that may arise with respect to age and schooling in the potential experience variable and away from measurement error in the direct measures of actual work experience. The objective here is to determine how the use of potential experience versus direct measures of actual work experience affect parameter estimates in earnings models and inferences about gender wage inequality from wage decompositions. Actual work experience as directly measured is the standard against which potential and predicted work experience effects are compared.

Our discussion of specification error will be framed in the simplest of models - a traditional (Mincerian) log wage equation,

$$
Y_{i}=\beta_{0}+\beta_{1} S_{i}+\beta_{2} X_{i}^{*}+\beta_{3} X_{i}^{* 2}+\sum_{i=1}^{K} \alpha_{i} H_{i}+\varepsilon_{i}, i=1, \ldots, N,
$$

where $Y$ is the natural $\log$ of the hourly wage, $S$ is the schooling level, $X^{*}$ is true/actual work experience, $H$ is a set of $K$ other control variables, $\varepsilon$ is a random error term, $i$ indexes the individual, and $N$ represents the sample size. ${ }^{2,3}$ More compactly, we can express (1) as,

\footnotetext{
${ }^{2}$ Bound and Solon (1999) discuss classical measurement error in schooling for a log wage model.

${ }^{3}$ For more rigorous theoretical treatments of errors-in-variables models see Y. Amemiya (1985) and Hausman et al. (1991).
} 


$$
Y=W^{*} \gamma+\varepsilon
$$

where $Y$ and $\varepsilon$ are $(N \times 1)$ vectors, $W^{*}$ is the $(N \times(K+4))$ observation matrix, and $\gamma$ is the $((K+4) \times 1)$ coefficient vector. Taking the probability limit of the OLS estimator,

$$
\operatorname{plim}(\widehat{\gamma})=\gamma+\Sigma_{W^{*} W^{*}}^{-1} \Sigma_{W^{*} \varepsilon}
$$

which is consistent only if $\operatorname{plim}\left(N^{-1} W^{*^{\prime}} \varepsilon\right)=\Sigma_{W^{*} \varepsilon}=0$. Thus, the regressors, specifically schooling and experience, must be exogenously determined (i.e. uncorrelated with $\varepsilon){ }^{4}$

Now suppose that true work experience, $X^{*}$, is unobserved. Instead one observes $X$, which can be thought of as potential work experience. Couching this in the traditional errors-in-variables model,

$$
X_{i}=X_{i}^{*}+v_{i}
$$

where $v$ is the measurement error. At this point we will assume non-classical measurement error in the sense that $v$ may be correlated with $X^{*}$ and that the mean of $v$ may not be, and most probably is not, zero. ${ }^{5}$ As is traditionally the case we will, however, assume that there is no correlation between $v$ and $\varepsilon$. Later we conduct tests of the classical measurement error assumptions.

\footnotetext{
${ }^{4}$ Several researchers have noted the endogenous nature of schooling (e.g., Bound and Solon, 1999; Black et al., 2000).

${ }^{5}$ The mean of $v$ could be positive if potential work experience overstates actual work experience, which is likely the case for many females. If, however, potential work experience understates one's actual work experience, which is more likely for those who work over-time or who hold multiple jobs, $E(v)$ would be negative.
} 
The nature of the measurement error we are considering is better viewed as a model misspecification problem. This can be seen by substituting (4) into (1) yielding,

$$
Y_{i}=\beta_{0}+\beta_{1} S_{i}+\beta_{2} X_{i}+\beta_{3} X_{i}^{2}+\sum_{i=1}^{K} \alpha_{i} H_{i}+\varepsilon_{i}^{*}
$$

where $\varepsilon_{i}^{*}$ is,

$$
\varepsilon_{i}^{*}=\varepsilon_{i}-\beta_{2} v_{i}-2 \beta_{3} X_{i}^{*} v_{i}-\beta_{3} v_{i}^{2} .
$$

More compactly, (5) can be expressed as,

$$
Y=W \gamma+\varepsilon^{*}
$$

where $W$ is the $(N \times(K+4))$ new observation matrix, and $\varepsilon^{*}$ is the new $(N \times 1)$ error vector. The error vector $\varepsilon^{*}$ may be expressed as,

$$
\varepsilon^{*}=\varepsilon-v \beta_{2}-2\left[X^{*} \odot v\right] \beta_{3}-[v \odot v] \beta_{3},
$$

where $X^{*} \odot v$ and $v \odot v$ are Hadamard products (i.e. element by element multiplication between $X^{*}$ and $v$ and between $v$ and $v$, respectively). ${ }^{6}$

The probability limit of the OLS estimates is,

$$
\begin{aligned}
\operatorname{plim}(\widehat{\gamma})= & \gamma+\Sigma_{W W}^{-1} \Sigma_{W \varepsilon}-\Sigma_{W W}^{-1} \Sigma_{W v} \beta_{2}-2 \Sigma_{W W}^{-1} \Sigma_{W, X^{*} \odot v} \beta_{3} \\
& -\Sigma_{W W}^{-1} \Sigma_{W, v \odot v} \beta_{3} \\
= & \gamma-\Sigma_{W W}^{-1} \Sigma_{W v} \beta_{2}-2 \Sigma_{W W}^{-1} \Sigma_{W, X^{*} \odot v} \beta_{3}-\Sigma_{W W}^{-1} \Sigma_{W, v \odot v} \beta_{3},
\end{aligned}
$$

assuming $\Sigma_{W W}^{-1} \Sigma_{W \varepsilon}=0$. Now, with specification error associated with substitution of $X$ for $X^{*}$, the asymptotic bias in $\widehat{\gamma}$ consists of three or four terms.

\footnotetext{
${ }^{6}$ In the present case, $X \odot v=[d(X)] v$ and $v \odot v=[d(v)] \odot v$, where $d(X)$ and $d(v)$ are $(N \times \mathrm{x} N)$ diagonal matrices formed by arraying the elements of vectors $X$ and $v$ along the principal diagonal. See Ding and Engle (2001) and Styan (1973) for more details.
} 
Our approach to correcting for specification error consists of modeling actual experience as a stochastic regressor generated from a semi-log model:

$$
\ln \left(X_{i}^{*}\right)=Z_{i} \gamma_{1}+\psi_{1 i}
$$

where $\psi_{1 i} \sim N\left(0, \sigma_{\psi_{1}}^{2}\right)$ and $Z$ is a set of regressors that includes the regressors in (1) (i.e. $S, H$ ) and a set of identifying variables (i.e. a respondent's age in 1990, a set of occupational dummy variables, and the number of children for females). ${ }^{7}$

The semi-log specification bounds $X_{i}^{*}$ away from zero. Our proposed correction procedure uses a predicted measure of actual work experience constructed in the following fashion:

$$
\widehat{X_{i}^{*}}=\exp \left(Z_{i} \hat{\gamma}_{1}+0.5 \tilde{\sigma}_{\psi_{1}}^{2}\right)
$$

where $\widehat{\gamma_{1}}$ is obtained from OLS estimation of (10) and $\tilde{\sigma}_{\psi_{1}}^{2}$ is obtained from the method of moments estimator

$$
\tilde{\sigma}_{\psi_{1}}^{2}=2\left[\ln \left(\sum_{i} X_{i}^{*}\right)-\ln \left(\sum_{i} \exp \left(Z_{i} \hat{\gamma}_{1}\right)\right)\right]
$$

that ensures that the sample mean of $\widehat{X^{*}}$ is identical to the sample mean of $X^{*}$, including even the sample lacking actual work experience (see Oaxaca and Ransom, 2003). ${ }^{8,9}$ Since $\ln \left(X_{i}^{* 2}\right)=2 \ln \left(X_{i}^{*}\right)$ it can be shown that the square of predicted work

\footnotetext{
${ }^{7}$ Note that the occupational dummies could have been included in the log wage equation. However, in order for the system of equations to be identified $Z$ needs to include some regressors that are not already included in $H$.

${ }^{8}$ While this procedure can be interpreted as instrumental variables, its motivation does not depend on endogeneity problems. Our motivation is to apply the correction model to data sets lacking information on actual experience.

${ }^{9}$ Instead of predicting $X^{*}$ directly, one could regress the measurement error, $v$, on the set of control variables, $Z$. Thus, $\widehat{v_{i}}=Z_{i} \widehat{\theta}$ where $\widehat{\theta}$ is unbiased and consistent under the standard assumptions on $u$, and $\widehat{v}$ can be used to construct $\widehat{X^{*}}$. Specifically, for the case in which measurement
} 
experience is obtained from

$$
\widehat{X_{i}^{* 2}}=\exp \left(Z_{i}\left(2 \hat{\gamma}_{1}\right)+0.5 \tilde{\sigma}_{\psi_{2}}^{2}\right)
$$

where

$$
\tilde{\sigma}_{\psi_{2}}^{2}=2\left[\ln \left(\sum_{i} X_{i}^{* 2}\right)-\ln \left(\sum_{i} \exp \left(Z_{i}\left(2 \hat{\gamma}_{1}\right)\right)\right)\right]
$$

which restricts the sample mean of $\widehat{X^{* 2}}$ to match that of $X^{* 2} \cdot{ }^{10}$

Our method of predicting work experience is more general than other methods used in the literature and is unique in its use of a semi-log model. For example, Garvey and Reimers (1980) use the 1968-1973 survey years of the NLSY66 to predict work experience measures for females. They focus on black females and white females ages 19 to 29. Actual work experience is constructed by summing lifetime hours spent working or training and dividing through by 2000. In this analysis OLS and Tobit are used to predict work experience measures by birth cohort. Garvey and Reimers regress the actual measure of work experience on a set of demographic variables which include a respondent's age, schooling level, race, marital status, number and ages of children, and health status. However, they do not extend their findings to data sets lacking actual work experience measures. Instead they compare the estimates obtained between the predicted and potential work experience measures. Filer (1992) uses a set of linear occupation-specific equations to predict work experience

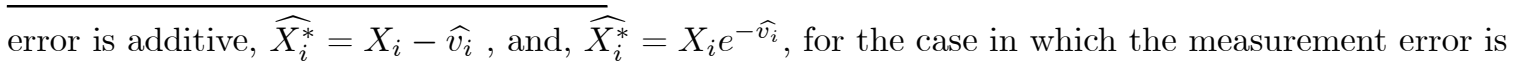
multiplicative. Additionally, further simplification of the additive case yields,

$$
\begin{aligned}
\widehat{X^{*}} & =\left[I_{N}-Z\left(Z^{\prime} Z\right)^{-1} Z^{\prime}\right] X+Z\left(Z^{\prime} Z\right)^{-1} Z^{\prime} X^{*} \\
& =X-Z \widehat{C}+Z \widehat{\delta},
\end{aligned}
$$

where $I_{N}$ is an $(N \times N)$ identity matrix, $\widehat{C}=\left(Z^{\prime} Z\right)^{-1} Z^{\prime} X$, and $\widehat{\delta}=\left(Z^{\prime} Z\right)^{-1} Z^{\prime} X^{*}$. Our method of predicting work experience differs from this method in that it omits two terms, $X$ and $-Z \widehat{C}$.

${ }^{10}$ An alternative would be to impose the restriction $\tilde{\sigma}_{\omega_{2}}=4 \tilde{\sigma}_{\omega_{1}}$. 
for females. He constructs actual measures of years of work experience by summing the weeks worked and dividing through by 52 thus ignoring employment status and multiple job holding. He estimates these equations using pooled data (i.e. 1966-1984) from the NLSY66 and extends his findings to the 1980 Census Public Use Microdata Tapes.

Our empirical implementation of (5) includes completed schooling, marital status, industry dummies, regional dummies, and SMSA (Standard Metropolitan Statistical Area) dummies as the set of control variables, $H .^{11}$

\section{DATA}

The data used in this paper come from the NLSY79, the PSID, and the IPUMS. We focus on 1990 because it is a Census year common to all of our data sets and permits analysis of relatively young cohorts as well as a more broadly defined age grouping. The NLSY79 consists of 12,686 young men and women, living in the U.S., who were between the ages of 14 and 22 when the first wave of the survey was conducted in 1979. The PSID is a longitudinal study that began in 1968. There were 4,800 families included in 1968 and the largest amount and most detailed information is collected for the head of the household. For this reason, amongst others, we restrict our sample to heads of household who are between the ages of 18 and 55 in 1990. The IPUMS is a collection of 25 cross-sectional samples spanning the 1850-

\footnotetext{
${ }^{11}$ Mincer and Polachek (1974) provide a different approach than that used in our paper but not an entirely different model. They argue that the simple Mincer earnings function, which uses potential work experience, is biased due to omitted variables rather than measurement error. Mincer and Polachek decompose potential work experience into actual (or instrumented) work experience and "home time" (i.e. time spent out of the labor force) and derive a segmented earnings function instead. This omitted variables approach may explain why our measurement error is non-classical and one-sided. We thank Solomon Polachek for these comments and insights. For further discussion of the life-cycle division of labor within a family unit see Polachek (1975).
} 
2000 U.S. Census years. To ensure comparability of our results across the data sets, we divided the IPUMS into two samples: 1) individuals between the ages of 25 and 33 in 1990; and 2) heads of household between the ages of 18 and 55 in 1990. The former construction most closely parallels the NLSY79 and the latter the PSID. In this paper, we abstract away from racial/ethnic issues by restricting our attention to whites.

The dependent variable used in the log wage equations is the hourly wage. We construct this measure by dividing the total income from wages and salary by the annual hours worked. For the NLSY79 and the PSID, the construction of the annual hours worked will be discussed below. For the IPUMS this measure is just the product of the weeks worked last year and the usual hours worked per week. The control variables, $H$, are defined as follows: The schooling variable corresponds to the highest grade completed as of 1990. MARRIED takes on a value of "1" if the individuals were married in 1990 and "0" otherwise (i.e. single, separated, annulled, divorced, or widowed). The industry dummies refer to the 1970 Census of the Population's Industry Classification System. The left-out reference group is public administration. The regional dummies correspond to the Northeast, North Central, West, and South regions of the U.S.. "West" is the omitted regional dummy. The SMSA dummies are: 1) not living in a SMSA; 2) living in a SMSA that is not a central city; 3) living in a SMSA where the central city is unknown; and 4) living in a SMSA with central city known. The omitted reference group is "not living in a SMSA."12

The actual work experience measures correspond to the "years" of full-time equiv-

\footnotetext{
${ }^{12}$ For the PSID, information on a respondent's SMSA is available only until 1986. Alternatively, we considered using city size indicators and rural/urban status. The IPUMS does not contain comparable measures for the city size indicators, however, and including a respondent's rural/urban status does not change the results significantly. Thus, the regressions corresponding to the heads of household, ages 18-55 do not include such measures.
} 
alent (FTE) work experience accumulated as of the 1990 interview. The analysis considers only those who report at least one year of FTE work experience. In constructing this measure for the NLSY79 we used the "hours worked on all jobs" each week for a given calendar year. We summed these figures for 1977 through 1989 and then divided the total by 2080 (40 hours per week $* 52$ weeks per year) to obtain a measure of FTE work experience. ${ }^{13}$

Information contained in the PSID family files on the "head's annual hours working for money" in 1967-1982 and the "head's total annual work hours" for 1983-1989 was used to construct actual work experience measures. Again, we summed the annual hours worked and divided through by 2080. Doing so produced figures that were implausibly low. ${ }^{14}$ Consequently, we redefined the actual work experience measures for the PSID in the following manner. First, we referenced the information contained in response to the question asking how many years an individual worked since the age of 18 years (inclusive). While the mean value of this variable is reasonable, this question elicited some unrealistic responses. For instance, there were several cases in which an individual reported having worked 98 years! Since this was obviously impossible, due to the fact that the oldest respondent considered was 55 years, we identified such individuals and assigned them the maximum allowable calendar years of work experience possible since the age of 18 . Next, we summed the number of years in which annual hours were reported. If,

\section{\# of years in which annual hours are reported}

$>$ max. allowable calendar years of work experience since the age of 18,

\footnotetext{
${ }^{13}$ Note that most often these "years" of work experience do not coincide with calendar years and actual work experience values would differ somewhat with alternative definitions of FTE.

${ }^{14}$ Part of the difficulty in using the PSID data is that the coding scheme does not allow one to distinguish between valid skips (i.e. missing information) and zero values.
} 
then the work experience measure used was simply the cumulative hours reported divided by 2080. If the above inequality did not hold, then we constructed the work experience measure as,

$$
\begin{aligned}
& \left(\frac{(\text { cumulative hours reported }) / 2080}{\# \text { of years in which annual hours are reported }}\right) * \\
& \text { (max. allowable calendar years of work experience since the age of } 18),
\end{aligned}
$$

which simply amounts to assigning the average annual work hours to those years in which such information was missing, plus the annual work hours as reported in the PSID. Doing so yielded much more reasonable estimates of an individual's work history as of $1990 .^{15}$

The potential work experience measure is calculated as follows,

$$
\text { Potential Work Experience }=\text { Age }_{1990}-\text { Schooling }_{1990}-6 \text {. }
$$

Our sample consists of white males and females with at least one year of actual (and potential) work experience accumulated as of 1990. We omit individuals who were missing information on any of the aforementioned variables and exclude military

\footnotetext{
${ }^{15}$ Both the NLSY79 and the PSID provide alternative measures of work experience. Specifically, the NLSY79 work history files contain hours worked in the past calendar year and the number of weeks worked per year. The PSID individual files also contain measures of the hours worked in a given year. Additionally, the PSID has information on the number of years a respondent has worked (full-time) since the age of 18 . The number of weeks worked per year and the number of years worked since the age of 18 are obviously better than proxied work experience (i.e. potential measures) but they contain a fair amount of measurement error and do not allow for differences in employment status or multiple-job holding. Blank (1988) finds that while being simultaneously determined, the hours worked per week decision are independent of the weeks worked per year decision. In spite of this we did, however, re-estimate (5) using these alternative definitions and the results do not differ much.
} 
personnel as well. In addition we also exclude Farmers and Farm Managers for the female heads of household regressions.

\section{ESTIMATION AND RESULTS}

Table 1 provides the descriptive statistics on the work experience measures across the data sets. The males, on average, have more work experience accumulated as of 1990 than the females. The NLSY79 males report 1.7 more years of FTE work experience than the females and the PSID males report 4.5 more years. For both data sets the potential work experience measures overstate time actually spent working. The differences are slight for the males but quite pronounced for the females. The problems are less severe for the NLSY79 because this data set contains a relatively young set of respondents. Overall, the most dramatic difference between the potential and actual work experience measures is for the PSID females; there is a 5.4 year discrepancy between the potential measure (17.8 FTE years) and the actual work experience measure (12.4 FTE years).

The descriptive statistics on the other control variables used in the log wage regressions can be found in the technical appendix which is available from the authors upon request. With few exceptions the sample characteristics were very nearly the same as between NLSY79 and IPUMS for the 25-33 year old group and between PSID and IPUMS for the 18-55 year old heads of household group. The main discrepancy was in the average hourly wage. The average hourly wage was consistently higher in the IPUMS data sets, ranging from only $\$ 0.13$ higher than the NLSY79 for the young male group to $\$ 2.79$ higher than the PSID for the 18-55 male heads of household group. The IPUMS hourly wage variable exhibited considerably higher variation as well. Because other sample characteristics match up quite closely, these discrepancies can be attributed to differences in how hourly wages had to be constructed because of differential data restrictions between IPUMS and the other data sets. A mitigating 
factor is that we are focusing on estimation and wage decomposition differences that arise from using actual and predicted experience compared with potential experience, within a given data set.

Based on the log wage regressions (available upon request from the authors) one can assess the extent of the bias correction for the estimated coefficients on schooling and work experience by referencing the absolute and mean percent differences. The absolute percent difference between the estimated coefficients for the log wage regressions using either the predicted or the potential experience measures versus actual work experience is,

$$
\left|\frac{{\widehat{\beta_{k}}}^{\text {predicted } \text { or potential }}-{\widehat{\beta_{k}}}^{\text {actual }}}{{\widehat{\beta_{k}}}^{\text {actual }}}\right| .
$$

The mean absolute percent difference for the returns to experience is just the average of (13) computed for the separate coefficients on the linear and quadratic experience terms. Regan et al. (2004) shows that in the Mincerian simple schooling model the coefficient on schooling is not identified because 1) this model is not based on an optimization framework, 2) does not control for ability (amongst other variables), and 3) is not concave in schooling. Consequently, one cannot interpret the coefficient on schooling as an internal rate of return. Nevertheless, for our purposes we will follow past convention and treat the coefficient on schooling as the effect of schooling on wages.

Table 2 reports the effects on schooling and experience coefficients from using predicted vs potential experience instead of actual experience. In the log wage regressions for the NLSY79 white males, we find that the effect of schooling is 1.3 vs 37.8 percent off when predicted work experience is used vs potential work experience in lieu of actual work experience. See columns 1 and 2, respectively. Similarly, the estimated coefficients on the linear and quadratic experience terms are 14.5 vs 61.7 and 53.6 
vs 95.7 percent off when predicted vs potential work experience is used in place of actual work experience. Thus, the average of the estimated coefficients for the experience variable is 34.0 vs 78.7 percent off when predicted work experience is used rather than potential experience. By comparing columns 1 and 2, one sees that the discrepancy on the schooling and experience coefficients are much larger when using potential work experience, instead of our predicted measure, in the log wage regression. For the NLSY79 females the pattern is similar with the exception of the estimated coefficients on quadratic experience. Using our predicted measure in lieu of potential experience creates a significantly larger departure from the estimated coefficient on actual experience squared. The peculiarities associated with the rates of return to work experience for the NLSY79 females may largely be stemming from the fact that this young sample has not accrued enough work experience to reach the concave portion of their wage-experience profile; the experience squared term only gains statistical significance when we use our predicted measure of work experience.

One can apply similar interpretations to the remaining figures in Table 2 corresponding to the PSID samples. We find that the log wage regressions using potential work experience overstate the effects of schooling relative to those using predicted work experience. With respect to the estimated rates of return to work, we again find that the log wage regressions using our predicted measures of work experience perform much better (relative to our actual experience measures) than those regressions using potential work experience Overall, we can take these findings as continued evidence for the need to employ better proxies than time elapsed since leaving school for female and male work histories when such information is lacking.

Tables 3-6 report our results on the effects of different measures of work experience on the male-female wage gap. We separate out the contributions to the wage decomposition of gender differences in the means and estimated coefficients associated with schooling, experience, and experience squared. The remaining contributions pertain 
to the constant term and the indicator variables and are summed and listed as 'other variables'. In reporting the estimates of discrimination (or the unexplained differential), the separate discriminatory components corresponding to the constant term and indicator variables are omitted because the estimated coefficients associated with these variables are not invariant to the choice of omitted reference groups [Oaxaca and Ransom (1999)]. Although the detailed endowment effects corresponding to the groups of indicator variables are invariant with respect to the choice of left out reference groups, they are not reported separately because the differences across the alternative measures of work experience were negligible.

Table 3 reports the decomposition results for the 25-33 age group from the NLSY79 sample. The unadjusted male-female wage differential is $0.224 \log$ points. For the log wage regression using actual work experience, the difference in average endowments account for $0.07 \log$ points of the unadjusted wage differential. The partial contributions of schooling and experience to the endowment effect are -0.032 and 0.067 , respectively and are reported in column 1. Similarly, for column 2 which corresponds to the log wage regression using predicted work experience, the endowment effects explain about 0.097 log points of the unadjusted wage differential. The schooling and experience endowment effects when using predicted experience correspond very closely to those estimated with actual experience. When work experience is measured as the time elapsed since leaving school (column 3), the endowment effects are 0.006. Thus the use of potential experience would imply that virtually all of the gender wage gap is unexplained. Columns (4) - (6) tell the same story. Using actual or even predicted experience yields lower estimates of discrimination compared with potential experience. We note that the separate estimated effects of the discrimination components differ significantly between actual and predicted experience (columns 4 and 5) although the overall sums do not differ very much. This has largely to do with the problem of capturing concavity of the wage/experience profile for this relatively 
young group of workers.

Table 4 reports the decomposition results for the 25-33 age group from the IPUMS sample. Actual work experience is missing from the IPUMS data so the comparison is between using a predicted work experience and using potential experience. The unadjusted gender wage gap of $0.223 \mathrm{log}$ points is virtually identical to that from the NLSY79 sample. The endowment effects account for 0.093 log points of the unadjusted gap when using predicted experience (column 1). On the other hand the use of potential experience would imply that virtually none of the unadjusted gap is the result of endowment differences (column 2). Columns 3 and 4 show that the corresponding estimate of discrimination is much smaller when using predicted experience. As was the case with the NLSY79, the use of potential experience would imply that virtually the entire gender wage gap for the $25-33$ year olds is the result of discrimination or at best is unexplained.

Turning next to the broader group of workers aged 18 to 55 who are heads of households, we report the decomposition results for the PSID sample in Table 5. The unadjusted gender wage gap is $0.297 \log$ points. Actual and predicted experience yield virtually identical estimates of the contribution of endowments at 0.226 and $0.224 \mathrm{log}$ points, respectively (columns 1 and 2). On the other hand potential experience yields a much lower estimate of the endowment effect (0.167 log points). Accordingly, actual and predicted experience yield virtually identical estimates of discrimination at around 0.07 log points (columns 4 and 5). The use of potential experience implies an estimate of discrimination or of the unexplained gap that is nearly twice (column 6 ) that obtained from using actual or predicted experience. Unlike the case for the younger workers in the NLSY79 dataset, the individual components of the discrimination estimates are very nearly the same as between actual and predicted experience (columns 4 and 5).

Finally, Table 6 reports the decomposition results for IPUMS sample of workers 
aged 18 to 55 who are heads of households. The unadjusted gender wage gap for this sample is 0.33 log points. Again, actual work experience is missing from the IPUMS dataset. The decomposition results follow the same pattern as found in the other samples. Endowment effects are larger and discrimination effects are correspondingly smaller when using predicted rather than potential experience.

Our analysis of work experience measures concludes with formal tests of the classical measurement error assumptions. The first hypothesis we test is,

$$
H_{0}: E(v)=0 ; H_{1}: E(v) \neq 0 .
$$

Testing the above hypothesis is akin to asking whether the average potential experience is (statistically significantly) different from the average actual experience. The following test statistic is used,

$$
\frac{\bar{v}}{\widehat{\sigma}_{v} / \sqrt{N}} \sim t \rightarrow N(0,1)
$$

where $\bar{v}=\frac{\sum_{i=1}^{N} v_{i}}{N}$ and $\widehat{\sigma}_{v}^{2}=\frac{\sum_{i=1}^{N}\left(v_{i}-\bar{v}\right)}{N-1}$. For both definitions of actual work experience in the NLSY79 and the PSID data sets, one can reject the null hypothesis at the five percent level of significance. Hence, the measurement error is non-classical in the sense that its mean is not zero. Referring back to Table 1, one sees that the potential work experience measures overstate the true accumulated work experience which suggests that the means of the measurement errors, on average, are positive.

For the case in which the measurement error is additive, the second hypothesis we test is,

$$
H_{0}: E\left(X_{i}^{*} v_{i}\right)=0 ; H_{1}: E\left(X_{i}^{*} v_{i}\right) \neq 0,
$$

which is testing whether or not there is covariance between the actual work experience and the measurement error. Testing the above hypothesis involves a regression of the 
measurement error on the actual work experience to determine if the estimated coefficient on $X_{i}^{*}$ is statistically significant. Specifically, because the estimated coefficient on $X_{i}^{*}$ is the ratio of covariance between $X_{i}^{*}$ and $v$ and the variance of $X_{i}^{*}$. Because the variance of $X_{i}^{*}$ cannot be zero, a significant estimated coefficient is rendered only when $\operatorname{cov}\left(X_{i}^{*}, v_{i}\right) \neq 0$. Similarly, if one assumes a multiplicative measurement error, one simply tests for covariance between $\ln \left(X_{i}^{*}\right)$ and $v_{i}$. Conducting the aforementioned regression in all cases yields statistically significant estimates of the coefficients on $X_{i}^{*}$ and $\ln \left(X_{i}^{*}\right)$. Thus, one can reject the null hypothesis and conclude that covariance does in fact exist between the measurement error and the (log) actual work experience measure.

\section{CONCLUDING REMARKS}

This paper employs data from the NLSY79, the PSID, and the IPUMS in investigating the bias inherent in human capital models that utilize potential, as opposed to actual, work experience measures. We address the issue in a broader sense by not confining the analysis to women, where the problems of measurement error are well-known and broadly accepted, but by expanding the discussion to include males who also experience lapses of employment. The NLSY79 and the PSID allow us to measure actual work experience and to construct predicted work experience measures that we apply to the IPUMS - a data set lacking individual work histories.

A series of log wage regressions are run utilizing the various measures of work experience - actual, predicted, and potential (as proxied by time elapsed since leaving schooling). On the basis of these findings, we conclude that specification error in work experience not only biases its coefficient but also that of schooling as well; potential work experience overstates the effects of schooling and the rates of return to labor market experience. The only exception to the latter is for the PSID females. Based on the figures in Table 2, the bias on the estimated coefficient of schooling is 
larger when potential work experience is used instead of our predicted work experience measure in human capital models. The mean absolute percent differences reveal a substantial reduction in the bias on the estimated coefficients on experience when our predicted measures are used. The only exception to this is for the NLSY79 females.

Discussions of wage differentials are always at the forefront of labor economics research. The discontinuous nature of female work patterns in particular, coupled with unemployment spells that affect both genders, and different labor market experiences (e.g., employment status) provide evidence that demands better proxies than potential work experience when actual work histories are lacking. Tables 3-6 support this claim. The wage decompositions suggest that more of the male-female wage gap is explained by the difference in average qualifications when our predicted measures of work experience are used in lieu of potential measures.

This paper does not find support for the assumptions that are typically imposed in discussions of (classical) measurement error. We conduct a test that confirms a non-zero mean for the measurement error. While the average measurement error is positive, there are cases in which potential work experience actually understate actual work histories due to over-time work, multiple-job holding, and our imposition of a FTE status. Lastly, we conduct a test that confirms correlation between the measurement error and the true work experience measure. While we assume no covariance between the measurement error and the random error in the log wage equation, we conclude that the measurement error in potential work experience measures is nonclassical and that the problem is more fruitfully viewed as one of misspecification.

Instrumental Variables (IV) is the traditional approach taken to correct classical measurement error. This paper has shown, however, that the measurement error in work experience is non-classical. Matters are further complicated because experience enters log wage equations linearly and quadratically as well. While Kelejian (1971) offers an alternative estimation strategy (i.e. non-linear 2SLS), identifying a set of 
unique instruments is not a trivial task. Basically, the problem with instrumenting potential experience (and its square) is that this assumes that the correct model specification requires potential experience but that in a given data set potential experience is measured with error. Thus, instrumenting potential experience would not solve the model misspecification problem. IV applied to potential experience produces biased wage decomposition components in both coefficient estimates and in the predicted mean work experience. 


\section{REFERENCES}

Ashenfelter, O. and A. Krueger, 1994, "Estimates of the Economic Return to Schooling from a New Sample of Twins," American Economic Review, 84, pp. 11571173.

Ashenfelter, O. and C. Rouse, 1998, "Income, Schooling, and Ability: Evidence from a New Sample of Identical Twins," Quarterly Journal of Economics, 113, pp. 253-284.

Barron, J.M., M.C. Berger, and D.A. Black, 1997, "How Well Do We Measure Training?" Journal of Labor Economics, 15, pp. 507-528.

Behrman, J.R. and M.R. Rosenzweig, 1999, "Ability Biases in Schooling Returns and Twins: A Test and New Estimates," Economics of Education Review, 18, pp. 159-167.

Black, D.A., M.C. Berger, and F.A. Scott, 2000, "Bounding Parameter Estimates with Nonclassical Measurement Error," American Statistical Association, 95, pp. 739-748.

Blank, R., 1988, "Simultaneously Modeling the Supply of Weeks and Hours of Work among Female Household Heads," Journal of Labor Economics, 6, pp. 177-204.

Bollinger, C.R, 1998, "Measurement Error in the Current Population Survey: A Nonparametric Look," Journal of Labor Economics, 16, pp. 576-594.

Bound, J. and A.B. Krueger, 1991, "The Extent of Measurement Error in Longitudinal Earnings Data: Do Two Wrongs Make a Right?" Journal of Labor Economics, 9 , pp. 1-24. 
Bound, J., G.J. Duncan, and W.L. Rodgers, 1996, "Evidence on the Validity of CrossSectional and Longitudinal Labor Market Data," Journal of Labor Economics, 12, pp. 345-368.

Duncan, G.J. and D.H. Hill, 1985, "An Investigation of the Extent and Consequences of Measurement Error in Labor-Economic Survey Data." Journal of Labor Economics, 3, pp. 508-532.

Filer, R.K., 1992, "The Usefulness of Predicted Values for Prior Work Experience in Analyzing Labor Market Outcomes for Women," Journal of Human Resources, pp. 519-537.

Flores-Lagunes, A. and A. Light, 2003, "Measurement Error in Schooling: Evidence from Samples of Siblings and Identical Twins," Work in Progress.

Fullerton Jr., H.N. and J.J. Byrne, 1976, "Length of Working Life for Men and Women, 1970," Monthly Labor Review, 99, pp. 31-35.

Garvey, N. and C. Reimers, 1980, "Predicted vs. Potential Work Experience in an Earnings Function for Young Women," Research in Labor Economics, 3, pp. 99-127.

Griliches, Z., 1979, "Sibling Models and Data in Economics: Beginnings of a Survey," Journal of Political Economy, 87, pp. S37-S64.

Hausman, J.A., W.K. Newey, H. Ichimura, and J.L. Powell, 1991, "Identification and Estimation of Polynomial Errors-in-Variables Models." Journal of Econometrics, 50, pp. 273-295.

Hyslop, D.R. and G. W. Imbens, 2001, "Bias from Classical and Other Forms of Measurement Error," Journal of Business 83 Economic Statistics, 19, pp. 475481. 
Kelejian, H.H., 1971, "Two-Stage Least Squares and Econometric Systems Linear in Parameters but Nonlinear in the Endogenous Variables," Journal of the American Statistical Association, 66, pp. 373-374.

Lee, L. and J.H. Sepanski, 1995, "Estimation of Linear and Nonlinear Errors-inVariables," Journal of the American Statistical Association, 90, pp. 130-140.

Marquis, K.H., M.S. Marquis, and J.M. Polich, 1986, "Response Bias and Reliability in Sensitive Topic Surveys," Journal of the American Statistical Association, 81, pp. 381-389.

Mincer, J. and S. Polachek, 1974, "Family Investments in Human Capital: Earnings of Women," Journal of Political Economy, 82, pp. S76-S108.

Moulton, B.R., 1986, "An Analysis of Female Work Experience Data Derived from Social Security Records," Journal of Economic and Social Measurement, 14, pp. 66-75.

Neumark, D., 1999, "Biases in Twin Estimates of the Return to Schooling," Economics of Education Review, 18, pp. 143-148.

Oaxaca, R.L. and M.R. Ransom, 2003, "Using Econometric Models for Intrafirm Equity Salary Adjustments," Journal of Economic Inequality, 1, pp. 221-249.

Oaxaca, R.L. and M.R. Ransom, 1999, "Identification in Detailed Wage Decompositions," Review of Economics and Statistics, 81, pp. 154-157.

Polachek, S., 1975, "Potential Biases in Measuring Male-Female Discrimination," Journal of Human Resources, 10, pp. 205-229.

Regan, T.L, R.L. Oaxaca, and G. Burdhardt, 2004, "A Human Capital Model of the Effects of Abilities and Family Background on Optimal Schooling Levels," Work in Progress. 
Rodgers, W.L., C. Brown, and G.J. Duncan, 1993, "Errors in Survey Reports of Earnings, Hours Worked, and Hourly Wages," Journal of the American Statistical Association, 88, pp. 1208-1218.

Rouse, C.E., 1999, "Further Estimates of the Economic Return to Schooling from a New Sample of Twins," Economics of Education Review, 18, pp. 149-157. 
TABLE 1

WORK EXPERIENCE MEASURES--DESCRIPTIVE STATISTICS

\begin{tabular}{|c|c|c|c|c|c|c|c|c|}
\hline \multirow[b]{4}{*}{ ACTUAL EXPERIENCE } & \multicolumn{4}{|c|}{ WHITE MALES, AGES 25-33 } & \multicolumn{4}{|c|}{ WHITE MALES, HEADS OF HOUSEHOLD, AGES 18-55 } \\
\hline & \multicolumn{2}{|c|}{$\begin{array}{l}\text { NLSY79 } \\
(N=2789)\end{array}$} & \multicolumn{2}{|c|}{$\begin{array}{c}\text { IPUMS } \\
(\mathrm{N}=3540)\end{array}$} & \multicolumn{2}{|c|}{$\begin{array}{c}\text { PSID } \\
(\mathrm{N}=2892) \\
\end{array}$} & \multicolumn{2}{|c|}{$\begin{array}{c}\text { IPUMS } \\
(\mathrm{N}=9098)\end{array}$} \\
\hline & Mean & Std.Dev. & Mean & Std.Dev. & Mean & Std.Dev. & Mean & Std.Dev. \\
\hline & 9.186 & 3.168 & --- & --- & 16.063 & 9.099 & --- & --- \\
\hline (ACTUAL EXPERIENCE) $^{2}$ & 94.423 & 61.396 & --- & --- & 340.780 & 373.201 & --- & --- \\
\hline PREDICTED EXPERIENCE & 9.186 & 1.982 & 9.186 & 2.174 & 16.063 & 9.754 & 16.063 & 9.888 \\
\hline (PREDICTED EXPERIENCE) $^{2}$ & 94.423 & 40.927 & 94.423 & 44.811 & 340.780 & 442.316 & 340.780 & 415.802 \\
\hline POTENTIAL EXPERIENCE & 9.715 & 3.265 & 10.057 & 3.504 & 17.129 & 8.813 & 18.612 & 9.293 \\
\hline \multirow[t]{4}{*}{ 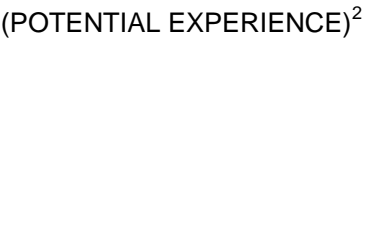 } & 105.027 & 64.892 & 113.423 & 76.242 & 371.046 & 350.948 & 432.748 & 379.450 \\
\hline & \multicolumn{4}{|c|}{ WHITE FEMALES, AGES 25-33 } & \multicolumn{4}{|c|}{ WHITE FEMALES, HEADS OF HOUSEHOLD, AGES $18-55$} \\
\hline & \multicolumn{2}{|c|}{$\begin{array}{l}\text { NLSY79 } \\
(\mathrm{N}=2386)\end{array}$} & \multicolumn{2}{|c|}{$\begin{array}{c}\text { IPUMS } \\
(\mathrm{N}=3062)\end{array}$} & \multicolumn{2}{|c|}{$\begin{array}{c}\text { PSID } \\
(\mathrm{N}=516)\end{array}$} & \multicolumn{2}{|c|}{$\begin{array}{c}\text { IPUMS } \\
(\mathrm{N}=2579)\end{array}$} \\
\hline & Mean & Std.Dev. & Mean & Std.Dev. & Mean & Std.Dev. & Mean & Std.Dev. \\
\hline ACTUAL EXPERIENCE & 7.495 & 2.813 & --- & --- & 12.385 & 8.037 & --- & --- \\
\hline$(A C T U A L \text { EXPERIENCE) })^{2}$ & 64.080 & 42.469 & --- & --- & 217.845 & 266.113 & --- & --- \\
\hline PREDICTED EXPERIENCE & 7.495 & 1.648 & 7.495 & 1.793 & 12.385 & 7.357 & 12.385 & 7.421 \\
\hline (PREDICTED EXPERIENCE) $^{2}$ & 64.080 & 28.288 & 64.080 & 31.184 & 217.845 & 267.480 & 217.845 & 282.849 \\
\hline POTENTIAL EXPERIENCE & 9.424 & 3.120 & 9.610 & 3.432 & 17.760 & 10.435 & 17.610 & 9.898 \\
\hline (POTENTIAL EXPERIENCE) $^{2}$ & 98.539 & 60.642 & 104.129 & 70.671 & 424.093 & 425.393 & 408.048 & 384.718 \\
\hline
\end{tabular}

note: ACTUAL and PREDICTED EXPERIENCE are constructed from hours worked per week for the NLSY79 and from total annual work hours as reported in the family files for the PSID Source of data: 1990 survey of the NLSY79, the PSID, and the IPUMS 
TABLE 2

ABSOLUTE \% DIFFERENCES AND MEAN ABSOLUTE \% DIFFERENCES FOR ESTIMATED COEFFICIENTS FOR SCHOOLING, EXPERIENCE, AND EXPERIENCE ${ }^{2}$

ABSOLUTE \% DIFF FOR SCHOOLING

ABSOLUTE \% DIFF FOR EXPERIENCE

ABSOLUTE \% DIFF FOR EXPERIENCE

MEAN ABSOLUTE \% DIFF FOR EXPERIENCE VARIABLE

ABSOLUTE \% DIFF FOR SCHOOLING

ABSOLUTE \% DIFF FOR EXPERIENCE

ABSOLUTE \% DIFF FOR EXPERIENCE

MEAN ABSOLUTE \% DIFF FOR EXPERIENCE VARIABLE

\begin{tabular}{|c|c|}
\hline \multicolumn{2}{|c|}{ WHITE MALES, AGES 25-33 } \\
\hline PREDICTED VS. ACTUAL & POTENTIAL VS. ACTUAL \\
\hline$\frac{(1)}{2}$ & $(2)$ \\
\hline $1.3 \%$ & $37.8 \%$ \\
\hline $14.5 \%$ & $61.7 \%$ \\
\hline $53.6 \%$ & $95.7 \%$ \\
\hline $34.0 \%$ & $78.7 \%$ \\
\hline
\end{tabular}

$34.0 \%$

$78.7 \%$ LSY79

WHITE FEMALES, AGES 25-33

$3.2 \%$ POTENTIAL VS. ACTUAL $11.0 \%$

$113.7 \%$

$115.7 \%$

$334.5 \%$

$161.0 \%$

$224.1 \%$

$138.3 \%$

\begin{tabular}{|c|c|}
\hline \multicolumn{2}{|c|}{ WHITE MALES, HEADS OF HOUSEHOLD, AGES 18-55 } \\
\hline PREDICTED VS. ACTUAL & POTENTIAL VS. ACTUAL \\
\hline (5) & $(6)$ \\
\hline $0.2 \%$ & $19.0 \%$ \\
\hline $0.8 \%$ & $8.3 \%$ \\
\hline $11.8 \%$ & $27.6 \%$ \\
\hline $6.3 \%$ & $18.0 \%$ \\
\hline
\end{tabular}

PSID

\begin{tabular}{|c|c|}
\hline EN & \\
\hline PREDICTED VS. ACTUAL & POTENTIAL VS. ACTUAL \\
\hline$(7)$ & $(8)$ \\
\hline $0.9 \%$ & $15.3 \%$ \\
\hline $7.0 \%$ & $37.2 \%$ \\
\hline $7.6 \%$ & $50.2 \%$ \\
\hline $7.3 \%$ & $43.7 \%$ \\
\hline
\end{tabular}

note: ACTUAL and PREDICTED EXPERIENCE are constructed from hours worked per week for the NLSY79 and from total annual work hours as reported in the family files for the PSID

Source of data: 1990 survey of the NLSY79 and the PSID 
TABLE 3

WAGE DECOMPOSITION: NLSY79

WHITE MALES AND FEMALES, AGES 25-33

(UNADJUSTED MALE/FEMALE WAGE DIFFERENTIAL $=0.224$ )

\begin{tabular}{|c|c|c|c|c|c|c|}
\hline & \multicolumn{3}{|c|}{ ENDOWMENT EFFECTS } & \multicolumn{3}{|c|}{ DISCRIMINATION } \\
\hline & $\frac{\text { ACTUAL }}{(1)}$ & $\frac{\text { PREDICTED }}{(2)}$ & $\begin{array}{l}\text { POTENTIAL } \\
(3)\end{array}$ & $\begin{array}{c}\text { ACTUAL } \\
(4)\end{array}$ & $\begin{array}{c}\text { PREDICTED } \\
(5) \\
\end{array}$ & $\begin{array}{l}\text { POTENTIAL } \\
(6)\end{array}$ \\
\hline SCHOOLING & -0.032 & -0.033 & -0.045 & -0.048 & 0.001 & 0.232 \\
\hline EXPERIENCE $^{2}$ & -0.107 & -0.050 & -0.001 & -0.153 & 0.210 & -0.083 \\
\hline OTHER VARIABLES & 0.034 & 0.030 & 0.040 & 0.011 & 0.171 & -0.388 \\
\hline TOTAL & 0.070 & 0.097 & 0.006 & 0.154 & 0.127 & 0.218 \\
\hline
\end{tabular}

note: ACTUAL and PREDICTED EXPERIENCE are constructed from hours worked per week for the NLSY79

Source of data: 1990 survey of the NLSY79 
TABLE 4

WAGE DECOMPOSITION: IPUMS

WHITE MALES AND FEMALES, AGES 25-33

(UNADJUSTED MALE/FEMALE WAGE DIFFERENTIAL=0.223)

ENDOWMENT EFFECTS

\begin{tabular}{|c|c|}
\hline PREDICTED & POTENTIAL \\
\hline$(1)$ & (2) \\
\hline-0.024 & -0.033 \\
\hline 0.197 & 0.009 \\
\hline-0.102 & 0.006 \\
\hline 0.022 & 0.032 \\
\hline 0.093 & 0.013 \\
\hline
\end{tabular}

DISCRIMINATION

\begin{tabular}{ccc}
\hline PREDICTED & & POTENTIAL \\
\cline { 1 - 1 }-0.079 & & -0.096 \\
0.041 & & 0.138 \\
0.023 & & -0.014 \\
0.145 & & 0.182 \\
& & \\
0.130 & & 0.210
\end{tabular}

note: PREDICTED EXPERIENCE is constructed from hours worked per week for the NLSY79

Source of data: 1990 survey of the IPUMS 
TABLE 5

WAGE DECOMPOSITION: PSID

WHITE MALES AND FEMALES, HEADS OF HOUSEHOLD, AGES 18-55 (UNADJUSTED MALE/FEMALE WAGE DIFFERENTIAL $=0.297$ )

\begin{tabular}{|c|c|c|c|c|c|c|}
\hline & \multicolumn{3}{|c|}{ ENDOWMENT EFFECTS } & \multicolumn{3}{|c|}{ DISCRIMINATION } \\
\hline & $\frac{\text { ACTUAL }}{(1)}$ & $\begin{array}{c}\text { PREDICTED } \\
(2)\end{array}$ & $\begin{array}{l}\text { POTENTIAL } \\
(3)\end{array}$ & $\frac{\text { ACTUAL }}{(4)}$ & $\begin{array}{c}\text { PREDICTED } \\
(5)\end{array}$ & $\begin{array}{l}\text { POTENTIAL } \\
(6)\end{array}$ \\
\hline SCHOOLING & 0.004 & 0.004 & 0.005 & -0.005 & -0.016 & 0.031 \\
\hline EXPERIENCE & 0.160 & 0.162 & -0.025 & 0.012 & -0.020 & 0.235 \\
\hline EXPERIENCE $^{2}$ & -0.100 & -0.089 & 0.031 & -0.010 & 0.024 & -0.088 \\
\hline OTHER VARIABLES & 0.162 & 0.147 & 0.156 & 0.074 & 0.085 & -0.048 \\
\hline TOTAL & 0.226 & 0.224 & 0.167 & 0.072 & 0.073 & 0.130 \\
\hline
\end{tabular}

note: ACTUAL and PREDICTED EXPERIENCE are constructed from total annual work hours as reported in the family files for the PSID

Source of data: 1990 survey of the PSID 
TABLE 6

WAGE DECOMPOSITIONS: IPUMS

WHITE MALES AND FEMALES, HEADS OF HOUSEHOLD, AGES 18-55

(UNADJUSTED MALE/FEMALE WAGE DIFFERENTIAL $=0.330$ )

\begin{tabular}{|c|c|c|c|c|}
\hline & \multicolumn{2}{|c|}{ ENDOWMENT EFFECTS } & \multicolumn{2}{|c|}{ DISCRIMINATION } \\
\hline & PREDICTED & POTENTIAL & PREDICTED & POTENTIAL \\
\hline & $(1)$ & (2) & (3) & $(4)$ \\
\hline SCHOOLING & -0.016 & -0.019 & -0.186 & -0.128 \\
\hline EXPERIENCE & 0.170 & 0.041 & 0.195 & 0.261 \\
\hline EXPERIENCE ${ }^{2}$ & -0.095 & -0.015 & -0.060 & -0.056 \\
\hline OTHER VARIABLES & 0.079 & 0.087 & 0.243 & 0.157 \\
\hline TOTAL & 0.138 & 0.095 & 0.192 & 0.235 \\
\hline
\end{tabular}

note: PREDICTED EXPERIENCE is constructed from total annual work hours as reported in the family files for the PSID

Source of data: 1990 survey of the IPUMS 
Technical Appendix 
TECHNICAL APPENDIX A.1

DESCRIPTIVE STATISTICS FOR WHITE MALES

MARRIED

SCHOOLING

AGE

TOTAL ANNUAL INCOME FROM WAGES AND SALARY

HOURLY WAGE

AGRICULTURE, FORESTRY, FISHING

MINING

CONSTRUCTION

TRANSPORTATION, COMMUNICATIONS, OTHER PUBLIC UTILITIES

WHOLESALE AND RETAIL TRADE

FINANCE, INSURANCE, REAL ESTATE

BUSINESS, REPAIR SERVICES

PERSONAL SERVICES

ENTERTAINMENT, RECREATION SERVICES

PROFESSIONAL, RELATED SERVICES

PUBLIC ADMINISTRATION

NORTHEAST

NORTH CENTRAL

SOUTH

WEST

NOT CENTRAL CITY

CENTRAL CITY UNKNOWN

CENTRAL CITY

Source of data: 1990 survey of the NLSY79, the PSID, and the IPUMS

\begin{tabular}{|c|c|c|c|}
\hline \multicolumn{4}{|c|}{ AGES 25-33 } \\
\hline \multicolumn{2}{|c|}{$\begin{array}{c}\text { NLSY79 } \\
(\mathrm{N}=2789)\end{array}$} & \multicolumn{2}{|c|}{$\begin{array}{c}\text { IPUMS } \\
(\mathrm{N}=3540)\end{array}$} \\
\hline Mean & Std.Dev. & Mean & Std.Dev. \\
\hline 0.576 & 0.494 & 0.590 & 0.492 \\
\hline 12.920 & 2.587 & 13.005 & 2.550 \\
\hline 28.635 & 2.270 & 29.062 & 2.564 \\
\hline 24447.700 & 17490.500 & 24008.900 & 17352.200 \\
\hline 11.354 & 11.669 & 13.239 & 49.602 \\
\hline 0.038 & 0.191 & 0.031 & 0.173 \\
\hline 0.014 & 0.119 & 0.012 & 0.107 \\
\hline 0.134 & 0.341 & 0.136 & 0.343 \\
\hline 0.256 & 0.437 & 0.243 & 0.429 \\
\hline 0.086 & 0.281 & 0.073 & 0.260 \\
\hline 0.183 & 0.387 & 0.204 & 0.403 \\
\hline 0.044 & 0.206 & 0.052 & 0.221 \\
\hline 0.077 & 0.266 & 0.064 & 0.244 \\
\hline 0.019 & 0.135 & 0.013 & 0.112 \\
\hline 0.014 & 0.117 & 0.018 & 0.132 \\
\hline 0.090 & 0.286 & 0.100 & 0.300 \\
\hline 0.044 & 0.205 & 0.056 & 0.230 \\
\hline 0.149 & 0.356 & 0.217 & 0.412 \\
\hline 0.284 & 0.451 & 0.246 & 0.431 \\
\hline 0.338 & 0.473 & 0.302 & 0.459 \\
\hline 0.228 & 0.420 & 0.236 & 0.424 \\
\hline 0.244 & 0.430 & 0.251 & 0.434 \\
\hline 0.341 & 0.474 & 0.319 & 0.466 \\
\hline 0.304 & 0.460 & 0.273 & 0.446 \\
\hline 0.111 & 0.314 & 0.157 & 0.364 \\
\hline
\end{tabular}

\begin{tabular}{|c|c|c|c|}
\hline \multicolumn{2}{|c|}{$\begin{array}{c}\text { PSID } \\
(\mathrm{N}=2892)\end{array}$} & \multicolumn{2}{|c|}{$\begin{array}{c}\text { IPUMS } \\
(\mathrm{N}=9098)\end{array}$} \\
\hline Mean & Std.Dev. & Mean & Std.Dev. \\
\hline 0.801 & 0.399 & 0.791 & 0.407 \\
\hline 12.965 & 2.870 & 13.346 & 2.812 \\
\hline 36.094 & 8.386 & 37.958 & 9.015 \\
\hline 30792.400 & 29136.000 & 33389.100 & 27629.700 \\
\hline 13.839 & 13.080 & 16.626 & 39.445 \\
\hline 0.029 & 0.169 & 0.026 & 0.158 \\
\hline 0.012 & 0.109 & 0.015 & 0.120 \\
\hline 0.102 & 0.303 & 0.116 & 0.321 \\
\hline 0.268 & 0.443 & 0.260 & 0.439 \\
\hline 0.103 & 0.304 & 0.086 & 0.281 \\
\hline 0.173 & 0.379 & 0.170 & 0.376 \\
\hline 0.043 & 0.203 & 0.053 & 0.223 \\
\hline 0.061 & 0.239 & 0.056 & 0.229 \\
\hline 0.016 & 0.126 & 0.013 & 0.111 \\
\hline 0.009 & 0.094 & 0.014 & 0.119 \\
\hline 0.107 & 0.309 & 0.120 & 0.325 \\
\hline 0.076 & 0.266 & 0.072 & 0.258 \\
\hline 0.177 & 0.381 & 0.205 & 0.403 \\
\hline 0.226 & 0.419 & 0.259 & 0.438 \\
\hline 0.365 & 0.482 & 0.326 & 0.469 \\
\hline 0.232 & 0.422 & 0.211 & 0.408 \\
\hline-- & --- & --- & --- \\
\hline-- & -- & -- & -- \\
\hline --- & --- & --- & --- \\
\hline--- & --- & --- & --- \\
\hline
\end{tabular}


TECHNICAL APPENDIX A.2

DESCRIPTIVE STATISTICS FOR WHITE FEMALES

MARRIED

SCHOOLING

AGE

TOTAL ANNUAL INCOME FROM WAGES AND SALARY

HOURLY WAGE

AGRICULTURE, FORESTRY, FISHING

MINING

CONSTRUCTION

TRANSPORTATION, COMMUNICATIONS, OTHER PUBLIC UTILITIES

WHOLESALE AND RETAIL TRADE

FINANCE, INSURANCE, REAL ESTATE

BUSINESS, REPAIR SERVICES

PERSONAL SERVICES

ENTERTAINMENT, RECREATION SERVICES

PROFESSIONAL, RELATED SERVICES

PUBLIC ADMINISTRATION

NORTHEAST

NORTH CENTRAL

SOUTH

WEST

NOT CENTRAL CITY

CENTRAL CITY UNKNOWN

CENTRAL CITY

Source of data: 1990 survey of the NLSY79, the PSID, and the IPUMS

\begin{tabular}{|c|c|c|c|}
\hline \multicolumn{2}{|c|}{$\begin{array}{c}N L S Y 79 \\
(N=2386)\end{array}$} & \multicolumn{2}{|c|}{$\begin{array}{c}\text { IPUMS } \\
(\mathrm{N}=3062)\end{array}$} \\
\hline Mean & Std.Dev. & Mean & Std.Dev. \\
\hline 0.609 & 0.488 & 0.637 & 0.481 \\
\hline 13.326 & 2.295 & 13.345 & 2.315 \\
\hline 28.749 & 2.262 & 28.955 & 2.570 \\
\hline 16345.300 & 12365.200 & 15745.200 & 12760.800 \\
\hline 9.566 & 14.520 & 9.700 & 10.497 \\
\hline 0.010 & 0.100 & 0.012 & 0.108 \\
\hline 0.003 & 0.054 & 0.001 & 0.036 \\
\hline 0.017 & 0.128 & 0.016 & 0.127 \\
\hline 0.157 & 0.364 & 0.153 & 0.360 \\
\hline 0.047 & 0.211 & 0.040 & 0.196 \\
\hline 0.212 & 0.409 & 0.213 & 0.409 \\
\hline 0.091 & 0.288 & 0.109 & 0.312 \\
\hline 0.060 & 0.238 & 0.056 & 0.230 \\
\hline 0.053 & 0.225 & 0.045 & 0.207 \\
\hline 0.011 & 0.104 & 0.018 & 0.132 \\
\hline 0.302 & 0.459 & 0.296 & 0.456 \\
\hline 0.037 & 0.189 & 0.042 & 0.200 \\
\hline 0.141 & 0.348 & 0.216 & 0.411 \\
\hline 0.273 & 0.446 & 0.249 & 0.433 \\
\hline 0.368 & 0.482 & 0.310 & 0.463 \\
\hline 0.218 & 0.413 & 0.225 & 0.417 \\
\hline 0.235 & 0.424 & 0.251 & 0.434 \\
\hline 0.344 & 0.475 & 0.332 & 0.471 \\
\hline 0.329 & 0.470 & 0.279 & 0.448 \\
\hline 0.092 & 0.289 & 0.138 & 0.345 \\
\hline
\end{tabular}

\begin{tabular}{|c|c|c|c|}
\hline \multicolumn{2}{|c|}{$\begin{array}{c}\mathrm{PSID} \\
(\mathrm{N}=516)\end{array}$} & \multicolumn{2}{|c|}{$\begin{array}{c}\text { IPUMS } \\
(\mathrm{N}=2579)\end{array}$} \\
\hline Mean & Std.Dev. & Mean & Std.Dev. \\
\hline 0.006 & 0.076 & 0.195 & 0.397 \\
\hline 12.915 & 2.883 & 13.541 & 2.534 \\
\hline 36.674 & 9.611 & 37.150 & 9.384 \\
\hline 19713.400 & 13152.700 & 20040.200 & 16000.500 \\
\hline 9.898 & 5.930 & 11.348 & 14.106 \\
\hline 0.010 & 0.098 & 0.007 & 0.086 \\
\hline 0.004 & 0.062 & 0.004 & 0.065 \\
\hline 0.008 & 0.088 & 0.015 & 0.121 \\
\hline 0.178 & 0.383 & 0.161 & 0.367 \\
\hline 0.041 & 0.198 & 0.039 & 0.194 \\
\hline 0.174 & 0.380 & 0.205 & 0.404 \\
\hline 0.081 & 0.274 & 0.080 & 0.271 \\
\hline 0.033 & 0.179 & 0.061 & 0.239 \\
\hline 0.072 & 0.258 & 0.035 & 0.185 \\
\hline 0.012 & 0.107 & 0.014 & 0.116 \\
\hline 0.326 & 0.469 & 0.326 & 0.469 \\
\hline 0.062 & 0.241 & 0.054 & 0.225 \\
\hline 0.203 & 0.403 & 0.220 & 0.414 \\
\hline 0.180 & 0.385 & 0.231 & 0.422 \\
\hline 0.380 & 0.486 & 0.314 & 0.464 \\
\hline 0.236 & 0.425 & 0.234 & 0.424 \\
\hline--- & --- & --- & --- \\
\hline --- & --- & --- & --- \\
\hline-- & --- & --- & --- \\
\hline --- & --- & --- & --- \\
\hline
\end{tabular}


TECHNICAL APPENDIX A.3

LOG WAGE REGRESSION FOR WHITE MALES, AGES 25-33

\begin{tabular}{|c|c|c|c|c|c|}
\hline \multirow[b]{2}{*}{ CONSTANT } & \multicolumn{3}{|c|}{ NLSY79 } & \multicolumn{2}{|c|}{ IPUMS } \\
\hline & $\begin{array}{c}(1) \\
0.528 \\
(5.358)^{\star \star \star}\end{array}$ & $\begin{array}{c}(2) \\
0.512 \\
(2.357)^{\star \star}\end{array}$ & $\begin{array}{c}(3) \\
0.335 \\
(2.425)^{\star \star}\end{array}$ & $\begin{array}{c}(4) \\
0.582 \\
(3.377)^{\star \star \star}\end{array}$ & $\begin{array}{c}(5) \\
0.650 \\
(5.805)^{\star \star \star}\end{array}$ \\
\hline SCHOOLING & $\begin{array}{l}7.986 \mathrm{E}-02 \\
(18.799)^{\star \star \star}\end{array}$ & $\begin{array}{l}8.089 \mathrm{E}-02 \\
(18.762)^{\star \star \star}\end{array}$ & $\begin{array}{c}0.110 \\
(18.577)^{\star \star \star}\end{array}$ & $\begin{array}{l}7.154 \mathrm{E}-02 \\
(18.089)^{\star \star \star}\end{array}$ & $\begin{array}{l}9.836 \mathrm{E}-02 \\
(18.537)^{\star \star \star}\end{array}$ \\
\hline ACTUAL EXPERIENCE & $\begin{array}{c}0.103 \\
(7.929)^{\star \star \star}\end{array}$ & --- & --- & --- & $\cdots$ \\
\hline$(\text { ACTUAL EXPERIENCE) })^{2}$ & $\begin{array}{l}-3.516 \mathrm{E}-03 \\
(-5.257)^{\star \star \star}\end{array}$ & --- & --- & --- & $\cdots$ \\
\hline PREDICTED EXPERIENCE & --- & $\begin{array}{c}8.819 \mathrm{E}-02 \\
(2.063)^{\star *}\end{array}$ & --- & $\begin{array}{c}0.116 \\
(3.499)^{\star \star \star}\end{array}$ & -- \\
\hline$(\text { PREDICTED EXPERIENCE) })^{2}$ & --- & $\begin{array}{c}-1.632 \mathrm{E}-03 \\
(-0.800)\end{array}$ & --- & $\begin{array}{c}-3.352 \mathrm{E}-03 \\
(-2.104)^{\star \star}\end{array}$ & --- \\
\hline POTENTIAL EXPERIENCE & --- & --- & $\begin{array}{l}3.946 \mathrm{E}-02 \\
(2.824)^{\star \star \star}\end{array}$ & --- & $\begin{array}{c}1.924 \mathrm{E}-02 \\
(1.775)^{\star}\end{array}$ \\
\hline$(\text { POTENTIAL EXPERIENCE) })^{2}$ & --- & --- & $\begin{array}{c}-1.528 \mathrm{E}-04 \\
(-0.227)\end{array}$ & --- & $\begin{array}{c}6.181 \mathrm{E}-04 \\
(1.239)\end{array}$ \\
\hline MARRIED & $\begin{array}{c}0.116 \\
(5.551)^{\star \star \star}\end{array}$ & $\begin{array}{l}8.092 \mathrm{E}-02 \\
(3.500)^{\star \star \star}\end{array}$ & $\begin{array}{c}0.149 \\
(7.137)^{\star \star \star}\end{array}$ & $\begin{array}{l}6.826 \mathrm{E}-02 \\
(3.241)^{\star \star \star}\end{array}$ & $\begin{array}{c}0.130 \\
(6.764)^{\star \star \star}\end{array}$ \\
\hline AGRICULTURE, FORESTRY, FISHING & $\begin{array}{c}-0.321 \\
(-4.578)^{\star \star \star}\end{array}$ & $\begin{array}{c}-0.359 \\
(-5.054)^{\star \star \star}\end{array}$ & $\begin{array}{c}-0.310 \\
(-4.362)^{\star \star \star}\end{array}$ & $\begin{array}{c}-0.518 \\
(-7.856)^{\star \star \star}\end{array}$ & $\begin{array}{c}-0.481 \\
(-7.308)^{\star \star \star}\end{array}$ \\
\hline MINING & $\begin{array}{c}0.144 \\
(1.510)\end{array}$ & $\begin{array}{c}0.122 \\
(1.260)\end{array}$ & $\begin{array}{c}0.152 \\
(1.570)\end{array}$ & $\begin{array}{c}-5.253 \mathrm{E}-02 \\
(-0.560)\end{array}$ & $\begin{array}{c}-2.764 \mathrm{E}-02 \\
(-0.294)\end{array}$ \\
\hline CONSTRUCTION & $\begin{array}{c}6.224 \mathrm{E}-02 \\
(1.125)\end{array}$ & $\begin{array}{c}4.877 \mathrm{E}-02 \\
(0.868)\end{array}$ & $\begin{array}{c}8.563 \mathrm{E}-02 \\
(1.526)\end{array}$ & $\begin{array}{c}-9.932 \mathrm{E}-02 \\
(-2.151)^{\star \star}\end{array}$ & $\begin{array}{c}-6.850 \mathrm{E}-02 \\
(-1.482)\end{array}$ \\
\hline MANUFACTURING & $\begin{array}{c}1.200 \mathrm{E}-02 \\
(0.234)\end{array}$ & $\begin{array}{c}-3.186 \mathrm{E}-03 \\
(-0.061)\end{array}$ & $\begin{array}{c}3.877 \mathrm{E}-02 \\
(0.744)\end{array}$ & $\begin{array}{c}-5.468 \mathrm{E}-02 \\
(-1.268)\end{array}$ & $\begin{array}{c}-2.201 \mathrm{E}-02 \\
(-0.511)\end{array}$ \\
\hline TRANSPORTATION, COMMUNICATIONS, OTHER PUBLIC UTILITIES & $\begin{array}{c}1.454 \mathrm{E}-02 \\
(0.250)\end{array}$ & $\begin{array}{c}-1.407 \mathrm{E}-02 \\
(-0.237)\end{array}$ & $\begin{array}{c}5.421 \mathrm{E}-02 \\
(0.920)\end{array}$ & $\begin{array}{c}-7.755 \mathrm{E}-02 \\
(-1.495)\end{array}$ & $\begin{array}{c}-1.867 \mathrm{E}-02 \\
(-0.363)\end{array}$ \\
\hline WHOLESALE AND RETAIL TRADE & $\begin{array}{c}-0.185 \\
(-3.506)^{\star \star \star}\end{array}$ & $\begin{array}{c}-0.210 \\
(-3.897)^{\star \star \star}\end{array}$ & $\begin{array}{c}-0.148 \\
(-2.764)^{\star \star \star}\end{array}$ & $\begin{array}{c}-0.253 \\
(-5.749)^{\star \star \star}\end{array}$ & $\begin{array}{c}-0.204 \\
(-4.655)^{\star \star \star}\end{array}$ \\
\hline FINANCE, INSURANCE, REAL ESTATE & $\begin{array}{c}0.126 \\
(1.893)^{\star}\end{array}$ & $\begin{array}{c}0.119 \\
(1.764)^{\star}\end{array}$ & $\begin{array}{c}0.139 \\
(2.060)^{\star \star}\end{array}$ & $\begin{array}{c}-0.111 \\
(-1.980)^{\star \star}\end{array}$ & $\begin{array}{c}-9.028 \mathrm{E}-02 \\
(-1.610)\end{array}$ \\
\hline BUSINESS, REPAIR SERVICES & $\begin{array}{c}-9.165 \mathrm{E}-02 \\
(-1.546)\end{array}$ & $\begin{array}{c}-0.112 \\
(-1.860)^{*}\end{array}$ & $\begin{array}{c}-7.622 \mathrm{E}-02 \\
(-1.267)\end{array}$ & $\begin{array}{c}-0.153 \\
(-2.884)^{\star \star \star}\end{array}$ & $\begin{array}{c}-0.124 \\
(-2.345)^{\star \star}\end{array}$ \\
\hline PERSONAL SERVICES & $\begin{array}{c}-0.251 \\
(-2.892)^{\star \star \star}\end{array}$ & $\begin{array}{c}-0.256 \\
(-2.914)^{\star \star \star}\end{array}$ & $\begin{array}{c}-0.248 \\
(-2.817)^{\star \star \star}\end{array}$ & $\begin{array}{c}-0.198 \\
(-2.203)^{\star \star}\end{array}$ & $\begin{array}{c}-0.190 \\
(-2.118)^{\star \star}\end{array}$ \\
\hline ENTERTAINMENT, RECREATION SERVICES & $\begin{array}{c}-0.291 \\
(-3.037)^{\star \star \star}\end{array}$ & $\begin{array}{c}-0.298 \\
(-3.067)^{\star \star \star}\end{array}$ & $\begin{array}{c}-0.304 \\
(-3.125)^{\star \star \star}\end{array}$ & $\begin{array}{c}-0.186 \\
(-2.362)^{\star \star}\end{array}$ & $\begin{array}{c}-0.189 \\
(-2.399)^{\star *}\end{array}$ \\
\hline PROFESSIONAL, RELATED SERVICES & $\begin{array}{c}-0.134 \\
(-2.308)^{\star \star}\end{array}$ & $\begin{array}{c}-0.128 \\
(-2.178)^{\star \star}\end{array}$ & $\begin{array}{c}-0.143 \\
(-2.426)^{\star \star}\end{array}$ & $\begin{array}{c}-0.218 \\
(-4.455)^{\star \star \star}\end{array}$ & $\begin{array}{c}-0.246 \\
(-4.995)^{\star \star \star}\end{array}$ \\
\hline NORTHEAST & $\begin{array}{c}5.307 \mathrm{E}-02 \\
(1.584)\end{array}$ & $\begin{array}{c}5.091 \mathrm{E}-02 \\
(1.501)\end{array}$ & $\begin{array}{c}6.371 \mathrm{E}-02 \\
(1.871)^{*}\end{array}$ & $\begin{array}{c}6.794 \mathrm{E}-02 \\
(2.484)^{\star \star}\end{array}$ & $\begin{array}{l}7.510 \mathrm{E}-02 \\
(2.738)^{\star \star \star}\end{array}$ \\
\hline NORTH CENTRAL & $\begin{array}{c}-5.072 \mathrm{E}-02 \\
(-1.807)^{*}\end{array}$ & $\begin{array}{c}-4.938 \mathrm{E}-02 \\
(-1.739)^{\star}\end{array}$ & $\begin{array}{c}-5.094 \mathrm{E}-02 \\
(-1.789)^{*}\end{array}$ & $\begin{array}{c}-2.252 \mathrm{E}-03 \\
(-0.083)\end{array}$ & $\begin{array}{c}-2.961 \mathrm{E}-03 \\
(-0.109)\end{array}$ \\
\hline SOUTH & $\begin{array}{c}-0.113 \\
(-4.194)^{\star \star \star}\end{array}$ & $\begin{array}{c}-0.114 \\
(-4.184)^{\star \star \star}\end{array}$ & $\begin{array}{c}-0.102 \\
(-3.727)^{\star \star \star}\end{array}$ & $\begin{array}{c}-5.997 \mathrm{E}-02 \\
(-2.353)^{\star \star}\end{array}$ & $\begin{array}{c}-5.206 \mathrm{E}-02 \\
(-2.037)^{\star *}\end{array}$ \\
\hline SMSA, NOT CENTRAL CITY & $\begin{array}{c}0.159 \\
(5.870)^{\star \star \star \star}\end{array}$ & $\begin{array}{c}0.151 \\
(5.493)^{\star \star \star}\end{array}$ & $\begin{array}{c}0.173 \\
(6.319)^{\star \star \star}\end{array}$ & $\begin{array}{c}0.236 \\
(9.184)^{\star \star \star \star}\end{array}$ & $\begin{array}{c}0.253 \\
(9.898)^{\star \star \star}\end{array}$ \\
\hline SMSA, CENTRAL CITY UNKNOWN & $\begin{array}{l}9.508 \mathrm{E}-02 \\
(3.447)^{\star \star \star}\end{array}$ & $\begin{array}{l}9.805 \mathrm{E}-02 \\
(3.510)^{\star \star \star}\end{array}$ & $\begin{array}{c}0.102 \\
(3.649)^{\star \star \star}\end{array}$ & $\begin{array}{c}0.141 \\
(5.516)^{\star \star \star}\end{array}$ & $\begin{array}{c}0.146 \\
(5.677)^{\star \star \star}\end{array}$ \\
\hline SMSA, CENTRAL CITY & $\begin{array}{c}0.106 \\
(2.830)^{\star \star \star}\end{array}$ & $\begin{array}{c}0.115 \\
(3.045)^{\star \star \star \star}\end{array}$ & $\begin{array}{c}8.792 \mathrm{E}-02 \\
(2.321)^{\star *}\end{array}$ & $\begin{array}{c}0.129 \\
(4.183)^{\star \star \star \star}\end{array}$ & $\begin{array}{c}0.100 \\
(3.230)^{\star \star \star}\end{array}$ \\
\hline $\mathrm{R}^{2}$ & 0.243 & 0.224 & 0.219 & 0.200 & 0.196 \\
\hline $\begin{array}{l}\text { adj. } R^{2} \\
\text { nobs. }\end{array}$ & $\begin{array}{l}0.237 \\
2789\end{array}$ & $\begin{array}{l}0.218 \\
2789\end{array}$ & $\begin{array}{l}0.213 \\
2789\end{array}$ & $\begin{array}{l}0.195 \\
3540\end{array}$ & $\begin{array}{l}0.191 \\
3540\end{array}$ \\
\hline rate of return to experience at 10 years & $3.283 \mathrm{E}-02$ & $5.555 \mathrm{E}-02$ & $3.640 \mathrm{E}-02$ & 4.922E-02 & $3.160 \mathrm{E}-02$ \\
\hline
\end{tabular}

$\mathrm{t}$-values are in parentheses
$* * \star=$ significant at the $1 \%$ level for a two-tailed $\mathrm{t}$-test

${ }^{* \star *}=$ significant at the $1 \%$ level for a two-tailed $t$-test

*=significant at the $10 \%$ level for a two-tailed $t$-test

0.103
$(7.929)$

$-3.516 \mathrm{E}-03$

$\frac{8.819 \mathrm{E}-02}{(2.063)^{* \star}}$

0.116
$(3.499)^{\star * \star}$

$-3.352 \mathrm{E}-03$

924E-02

$81 \mathrm{E}-04$

$(5.551)^{\star}$

$(6.764)^{\star \star \star}$

$(-4.578)^{\star \star \star}$

$(-5.054)^{\star *}$ 
TECHNICAL APPENDIX A.4

CONSTANT

SCHOOLING

ACTUAL EXPERIENCE

(ACTUAL EXPERIENCE) $)^{2}$

PREDICTED EXPERIENCE

(PREDICTED EXPERIENCE) $)^{2}$

POTENTIAL EXPERIENCE

(POTENTIAL EXPERIENCE) ${ }^{2}$

MARRIED

AGRICULTURE, FORESTRY, FISHING

MINING

CONSTRUCTION

MANUFACTURING

TRANSPORTATION, COMMUNICATIONS, OTHER PUBLIC UTILITIES

WHOLESALE AND RETAIL TRADE

FINANCE, INSURANCE, REAL ESTATE

BUSINESS, REPAIR SERVICES

PERSONAL SERVICES

ENTERTAINMENT, RECREATION SERVICES

PROFESSIONAL, RELATED SERVICES

NORTHEAST

NORTH CENTRAL

SOUTH

$\mathrm{R}^{2}$

adj. $R^{2}$

nobs.

rate of return to experience at 10 years

$\mathrm{t}$-values are in parenthese

***=significant at the $1 \%$ level for a two-tailed t-test

${ }^{* *}=$ significant at the $5 \%$ level for a two-tailed t-test

*=significant at the $10 \%$ level for a two-tailed t-test

note: ACTUAL and PREDICTED WORK EXPERIENCE are constructed from total annual work hours as reported in the family files and POTENTIAL WORK EXPERIENCE=age-schooli

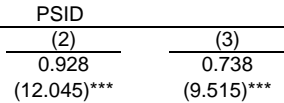

\begin{tabular}{|c|c|c|}
\hline (1) & (2) & (3) \\
\hline 0.951 & 0.928 & 0.738 \\
\hline$(12.970)^{\star \star \star}$ & $(12.045)^{\star \star \star}$ & $(9.515)^{\star \star \star}$ \\
\hline
\end{tabular}

7.596E-02 7.581E-02 9.039E-02 $(19.964)^{\star * *}$

$(19.940)^{\star \star \star} \quad(22.190)^{\star \star \star}$

4.363E-02

$(11.938)^{\star * *}$

$-8.165 \mathrm{E}-04$

$(-9.218)^{\star \star \star}$

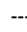

$-$

$(9.201)^{\star * *}$

$(-5.362)^{\star \star *}$

0.179

$(6.949)^{\star \star *}$

$-0.480$

$(-6.894)^{\star \star \star}$

0.131

(1.337)

$-3.690 \mathrm{E}-03$

$(-0.076)$

5.351E-02

(1.286)

9.839E-02 $(2.052)^{\star \star}$

$-0.139$

$(-3.176)^{\star \star \star}$

$-4.466 \mathrm{E}-02$

$(-0.739)$

$-8.000 \mathrm{E}-02$

$(-1.466)$

$-0.264$

$(-3.036)^{\star \star \star}$

5.628E-02

(0.504)

$-2.556 \mathrm{E}-02$

$(-0.535)$

0.116

$(3.636)^{\star \star \star}$

$-4.904 \mathrm{E}-02$

$(-1.642)$

-0.166
$(-6.208)^{\star \star \star}$

$(-6.208)^{\star \star \star}$

0.277

0.272

2982

2.730E-02
(9.201)

4.399E-02

$(11.273)^{\star \star \star}$

$-7.201 \mathrm{E}-04$

$(-8.451)^{\star \star \star}$

0.165

$(6.422)^{\star \star \star}$

$-0.469$

0.139

(1.416)

1.467E-02

(0.301)

5.932E-02

(1.430)

$9.468 \mathrm{E}-02$

$(2.109)^{\star \star}$

$-0.138$

$(-3.158)^{\star \star \star}$

$-4.469 \mathrm{E}-02$

$(-0.741)$

$-6.203 E-02$

$(-1.138)$

$-0.272$

$(-3.127)^{\star \star \star}$

5.038E-02

(0.452)

$-2.114 \mathrm{E}-02$

$(-0.444)$

0.115

$(3.611)^{\star \star \star}$

$-4.907 \mathrm{E}-02$

$(-1.647)^{*}$

$-0.168$

$(-6.318)^{\star \star \star}$

0.280

0.276

2892

2.959E-02
$-0.475$

$(-6.867)^{\star \star \star}$

0.150

(1.538)

$-8.619 \mathrm{E}-03$

(-0.178)

5.812E-02

(1.408)

9.547E-02

$(2.006)^{\star *}$

$-0.135$

$(-3.105)^{\star \star \star}$

$-4.755 \mathrm{E}-02$

$(-0.793)$

$-6.571 \mathrm{E}-02$

$(-1.213)$

$-0.289$

$(-3.353)^{\star * \star}$

3.129E-02

$-4.454 \mathrm{E}-02$

$(-0.939)$

0.108

$(3.397)^{\star \star * *}$

$-5.698 \mathrm{E}-02$

$(-1.923)^{\star}$

$-0.171$

$(-6.467)^{\star \star \star}$

0.288

0.283

2892

2.817E-02

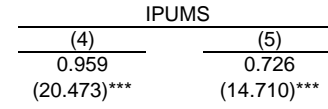

8.275E-02 9.709E-02

$(34.467)^{\star \star \star} \quad(38.668)^{\star \star \star}$

$-$

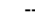

4.615E-02

$(18.676)^{\star \star \star}$

$-7.731 \mathrm{E}-04$

$(-13.250)^{\star \star \star}$

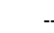

$4.121 \mathrm{E}-02$
$--\quad(15.427)^{\star \star \star}$

$---5.905 E-04$

$(-8.971)^{\star * *}$

$(6.024)^{\star \star \star} \quad(6.663)^{\star \star \star}$

$\begin{array}{ll}-0.481 & -0.483\end{array}$

$(-10.782)^{\star \star \star} \quad(-10.869)^{\star \star \star}$

$0.168 \quad 0.194$

$(3.028)^{\star \star \star} \quad(3.507)^{\star \star \star}$

5.837E-03 -7.787E-03

$(0.200) \quad(-0.269)$

(0.184)

3.513E-02 4.411E-02

(1.142) (1.439)

$\begin{array}{cc}-0.136 & -0.123 \\ (-5.015)^{\star \star *} & (-4.542)^{\star \star *}\end{array}$

5.680E-02 7.221E-02

(1.626) (2.071)**

$-6.729 \mathrm{E}-02 \quad-6.889 \mathrm{E}-02$

$(-1.959)^{\star} \quad(-2.013)^{\star \star}$

$-0.186 \quad-0.202$

$(-3.151)^{\star \star \star} \quad(-3.452)^{\star \star \star}$

$\begin{array}{cr}-7.174 \mathrm{E}-02 & -0.104 \\ (-1.287) & (-1.865)\end{array}$

$-0.117 \quad-0.134$

$(-4.008)^{\star \star \star} \quad(-4.603)^{\star \star \star}$

5.076E-02 5.127E-02

$(2.678)^{\star \star \star} \quad(2.713)^{\star \star \star}$

$-6.409 \mathrm{E}-02 \quad-6.613 \mathrm{E}-02$

$-0.107 \quad-0.110$

$(-6.277)^{\star \star \star} \quad(-6.462)^{\star \star \star}$

$0.241 \quad 0.246$

$0.240 \quad 0.245$

$\begin{array}{cc}9098 & 9098 \\ 3.069 \mathrm{E}-02 & 2940 \mathrm{E}-02\end{array}$
9.281E-02 $\quad 0.102$

4.747E-03 1.362E-02

$(-3.572)^{\star \star \star} \quad(-3.698)^{\star \star \star}$ 
TECHNICAL APPENDIX A.5

LOG WAGE REGRESSION FOR WHITE FEMALES, AGES 25-33

CONSTANT

SCHOOLING

ACTUAL EXPERIENCE

(ACTUAL EXPERIENCE) $^{2}$

PREDICTED EXPERIENCE

(PREDICTED EXPERIENCE) $^{2}$

POTENTIAL EXPERIENCE

(POTENTIAL EXPERIENCE) $)^{2}$

MARRIED

AGRICULTURE, FORESTRY, FISHING

MINING

CONSTRUCTION

MANUFACTURING

TRANSPORTATION, COMMUNICATIONS, OTHER PUBLIC UTILITIES

WHOLESALE AND RETAIL TRADE

FINANCE, INSURANCE, REAL ESTATE

BUSINESS, REPAIR SERVICES

PERSONAL SERVICES

ENTERTAINMENT, RECREATION SERVICES

PROFESSIONAL, RELATED SERVICES

NORTHEAST

NORTH CENTRAL

SOUTH

SMSA, NOT CENTRAL CITY

SMSA, CENTRAL CITY UNKNOWN

SMSA, CENTRAL CITY

$\mathrm{R}^{2}$

adj. $R^{2}$

rate of return to experience at 10 years

t-values are in parenthese

$* * *=$ significant at the $1 \%$ level for a two-tailed t-test

${ }^{* *}=$ significant at the $5 \%$ level for a two-tailed $t$-test

${ }^{*}=$ significant at the $10 \%$ level for a two-tailed $t$-test
NLSY79

$\frac{(1)}{0.568}$
$(5.040)^{\star \star \star}$
$8.347 \mathrm{E}-02$
$(15.095)^{\star \star \star}$
$5.715 \mathrm{E}-02$
$(3.043)^{\star \star \star}$
$-1.129 \mathrm{E}-03$
$(-0.911)$
---

$--$

$$
--
$$

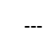$$
-
$$

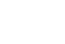

2.584E-02

(1.077)

-0.328
$(-2.516)$

$7.594 \mathrm{E}-02$

$$
\begin{aligned}
& 7.594 \mathrm{E}-02 \\
& (0.343)
\end{aligned}
$$

$$
0.100
$$

$(0.929)$

$-6.563 \mathrm{E}-03$

$(-0.098)$

6.555E-02

(0.813)

$-0.201$

$(-3.070)^{\star * \star *}$

$-7.193 \mathrm{E}-02$

$(-1.008)$

$-4.658 \mathrm{E}-03$

$(-0.061)$

$-0.444$

$(-5.640)^{\star \star \star}$

$-0.303$

$(-2.404)^{\star \star}$

$-7.504 \mathrm{E}-02$

(-1.172)

$-4.577 \mathrm{E}-03$

(-0.114)

$-8.664 \mathrm{E}-02$

$(-2.597)^{\star \star \star \star}$

$-0.127$

$(-4.023)^{\star * *}$

0.148

$(4.645)^{\star \star \star}$

0.170

$(5.310)^{\star \star \star *}$

0.276

$(5.940)^{\star \star \star}$

0.226

0.220
2386

3.458E-02

$(1.763)^{\star}$

8.079E-02

$(14.013)^{\star \star \star *}$

---

--

0.122
$(2.436)$

$-4.904 \mathrm{E}-03$

$(-1.692)^{*}$

$$
\text { --- }
$$$$
\text { -- }
$$

2.290E-02

(0.943)

$-0.324$

$(-2.442)^{\star *}$

7.722E-02

(0.343)

0.117

$-4.571 \mathrm{E}-03$

$(-0.067)$

6.604E-02

(0.807)

$-0.197$

$(-2.944)^{\star \star \star}$

$-7.339 \mathrm{E}-02$

(-1.015)

2.383E-03

(0.031)

$-0.442$

$(-5.491)^{\star \star \star *}$

$-0.299$

$(-2.342)^{\star \star}$

$-7.196 \mathrm{E}-02$

$(-1.100)$

$-6.682 \mathrm{E}-03$

$(-0.164)$

$-8.551 \mathrm{E}-02$

$(-2.527)^{\star *}$

-0.130
$(-4.028)^{\star \star \star}$

0.140
$(4.272)^{\star \star \star \star}$

0.163

$(4.964)^{\star \star \star ~}$

0.268

$(5.678)^{\star \star * *}$

0.204

0.204
0.197
2386

2.404E-02 $\frac{(2)}{0.365} \quad \frac{(3)}{0.818}$

$(4.797)^{\star \star \star}$

$9.262 \mathrm{E}-02$

$(12.386)^{\star \star \star}$

$--$

$--$

$--$

$--$

$-8.948 \mathrm{E}-03$

$(-0.522)$

6.887E-04

(0.805)

$2.479 \mathrm{E}-02$
$(1.013)$

$-0.375$

$(-2.828)^{* \star \star}$

4.875E-02

(0.216)

4.726E-02

(0.430)

$(-0.198)$

5.635E-02

(0.685)

$-0.232$

$(-3.482)^{\star * \star}$

$-6.870 \mathrm{E}-02$

$(-0.944)$

$-4.783 \mathrm{E}-02$

$(-0.614)$

-0.498
$(-6.223)^{\star \star \star}$

$-0.327$

$(-2.548)^{\star *}$

$-0.111$

$(-1.703)^{\star}$

1.103E-02

(0.269)

$-7.621 \mathrm{E}-02$

$(-2.242)^{\star \star}$

-0.108
$(-3.371)^{\star * *}$

0.196

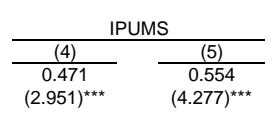

$7.749 \mathrm{E}-02 \quad 0.106$
$(16.610)$

$(16.610)^{\star \star \star} \quad(17.549)^{\star \star \star}$

---

$--$

$--$

0.111
$(2.940)^{\star \star \star}$

$-3.709 \mathrm{E}-03$

$(-1.729)^{*}$

--- $\quad 4.875 \mathrm{E}-03$

$(0.409)$

--- $\quad$ 7.494E-04

(1.300)

1.810E-02 1.364E-02

$\begin{array}{ll}(0.873) & (0.629)\end{array}$

$\begin{array}{cc}-0.238 & -0.333 \\ (-2.300)^{\star \star} & (-3.203)^{\star \star \star}\end{array}$

$-5.829 \mathrm{E}-02 \quad-2.415 \mathrm{E}-02$

$(-0.211) \quad(-0.087)$

$-8.441 \mathrm{E}-02 \quad-0.156$

$(-0.928) \quad(-1.717)^{*}$

$\begin{array}{ll}-0.114 & -0.120\end{array}$

$(-2.086)^{\star \star} \quad(-2.180)^{\star \star}$

3.067E-02 2.578E-02

$\begin{array}{ll}(0.445) & (0.372)\end{array}$

$\begin{array}{cc}-0.277 & -0.317 \\ (-5.211)^{\star \star \star} & (-5.956)^{\star \star \star}\end{array}$

$-8.495 \mathrm{E}-02 \quad-7.088 \mathrm{E}-02$

$(-1.503) \quad(-1.245)$

$-8.384 \mathrm{E}-02 \quad-0.122$

$(-1.313) \quad(-1.908)^{*}$

$-0.359 \quad-0.396$

$(-5.333)^{\star \star \star} \quad(-5.878)^{\star \star \star}$

$\begin{array}{ll}-0.222 & -0.228\end{array}$

$(-2.521)^{\star \star} \quad(-2.575)^{\star *}$

$-9.357 \mathrm{E}-02 \quad-0.145$

$(-1.808)^{*} \quad(-2.810)^{\star \star * *}$

7.276E-03 2.651E-02

(0.243) (0.883)

$-7.570 \mathrm{E}-02 \quad-6.147 \mathrm{E}-02$

$(-2.572)^{\star \star} \quad(-2.076)^{\star \star}$

$-0.108 \quad-7.986 \mathrm{E}-02$

$(-3.856)^{\star \star \star} \quad(-2.861)^{\star \star \star}$

$\begin{array}{lll}0.168 & 0.218 & 0.255\end{array}$

$\begin{array}{ccc}(5.174)^{\star \star \star} & (7.910)^{\star \star \star} & (9.344)^{\star \star \star}\end{array}$

$0.192-0.129-0.168$

$\begin{array}{ccc}(5.895)^{\star \star \star} & 0.129 & 0.168 \\ & (4.660)^{\star \star \star} & (6.094)^{\star \star \star}\end{array}$

$\begin{array}{lll}0.291 & 0.297 & 0.319\end{array}$

$(6.143)^{\star \star *} \quad(8.655)^{\star \star \star} \quad(9.221)^{\star \star \star}$

$\begin{array}{ll}0.234 & 0.227 \\ 0.229 & 0.221\end{array}$

$3062 \quad 3062$

3.654E-02 1.986E-02

note: ACTUAL and PREDICTED WORK EXPERIENCE are constructed from hours worked per week and POTENTIAL WORK EXPERIENCE=age-schooling-6

Source of data: 1990 survey of the NLSY79 and the IPUMS 
TECHNICAL APPENDIX A.6

LOG WAGE REGRESSION FOR WHITE FEMALES, HEADS OF HOUSEHOLD, AGES 18-55

\begin{tabular}{|c|c|c|c|c|c|}
\hline \multirow[t]{2}{*}{ DATA SOURCE: } & \multicolumn{3}{|c|}{ PSID } & \multicolumn{2}{|c|}{ IPUMS } \\
\hline & (1) & $(2)$ & (3) & (4) & (5) \\
\hline CONSTANT & 1.039 & 0.995 & 0.977 & 0.774 & 0.668 \\
\hline & $(6.652)^{\star \star \star}$ & $(5.927)^{\star \star \star}$ & $(5.824)^{\star \star \star}$ & $(8.270)^{\star \star \star}$ & $(6.834)^{\star \star \star}$ \\
\hline SCHOOLING & $7.631 \mathrm{E}-02$ & $7.701 \mathrm{E}-02$ & $8.801 \mathrm{E}-02$ & $9.649 \mathrm{E}-02$ & 0.107 \\
\hline ACTUAL EXPERIENCE & $\begin{array}{l}4.264 \mathrm{E}-02 \\
(5.068)^{\star \star \star}\end{array}$ & --- & --- & --- & --- \\
\hline$(A C T U A L \text { EXPERIENCE) })^{2}$ & $\begin{array}{c}-7.710 \mathrm{E}-04 \\
(-3.063)^{\star \star \star}\end{array}$ & --- & --- & --- & --- \\
\hline PREDICTED EXPERIENCE & & $\begin{array}{l}4.563 \mathrm{E}-02 \\
(4.472)^{\star \star \star}\end{array}$ & -- & $\begin{array}{l}3.040 \mathrm{E}-02 \\
(6.247)^{\star \star \star}\end{array}$ & --- \\
\hline$\left(^{(P R E D I C T E D ~ E X P E R I E N C E)}\right)^{2}$ & & $\begin{array}{c}-8.297 \mathrm{E}-04 \\
(-2.991)^{\star \star \star}\end{array}$ & -- & $\begin{array}{c}-4.979 \mathrm{E}-04 \\
(-3.927)^{\star \star \star}\end{array}$ & --- \\
\hline POTENTIAL EXPERIENCE & & --- & $\begin{array}{l}2.676 \mathrm{E}-02 \\
(3.613)^{\star \star \star}\end{array}$ & --- & $\begin{array}{l}2.638 \mathrm{E}-02 \\
(6.229)^{\star * \star}\end{array}$ \\
\hline (POTENTIAL EXPERIENCE) $^{2}$ & & --- & $\begin{array}{c}-3.840 \mathrm{E}-04 \\
(-2.039)^{\star \star}\end{array}$ & --- & $\begin{array}{c}-4.542 \mathrm{E}-04 \\
(-4.118)^{\star \star \star}\end{array}$ \\
\hline MARRIED & $\begin{array}{c}-0.316 \\
(-1.187)\end{array}$ & $\begin{array}{c}-0.310 \\
(-1.146)\end{array}$ & $\begin{array}{c}-0.348 \\
(-1.277)\end{array}$ & $\begin{array}{c}1.230 \mathrm{E}-02 \\
(0.431)\end{array}$ & $\begin{array}{c}-3.670 \mathrm{E}-02 \\
(-1.305)\end{array}$ \\
\hline AGRICULTURE, FORESTRY, FISHING & $\begin{array}{c}-0.441 \\
(-2.226)^{\star \star}\end{array}$ & $\begin{array}{c}-0.439 \\
(-1.929)^{\star}\end{array}$ & $\begin{array}{c}-0.430 \\
(-1.880)^{\star}\end{array}$ & $\begin{array}{c}-0.403 \\
(-2.888)^{\star \star \star}\end{array}$ & $\begin{array}{c}-0.375 \\
(-2.715)^{\star \star \star}\end{array}$ \\
\hline MINING & $\begin{array}{c}3.737 \mathrm{E}-03 \\
(-0.011)\end{array}$ & $\begin{array}{c}5.644 \mathrm{E}-04 \\
(0.002)\end{array}$ & $\begin{array}{c}-8.823 E-02 \\
(-0.260)\end{array}$ & $\begin{array}{c}0.197 \\
(1.115)\end{array}$ & $\begin{array}{c}0.185 \\
(1.046)\end{array}$ \\
\hline CONSTRUCTION & $\begin{array}{c}1.647 \mathrm{E}-02 \\
(-0.068)\end{array}$ & $\begin{array}{c}1.078 \mathrm{E}-02 \\
(0.044)\end{array}$ & $\begin{array}{c}3.757 \mathrm{E}-03 \\
(-0.015)\end{array}$ & $\begin{array}{c}-7.195 E-02 \\
(-0.697)\end{array}$ & $\begin{array}{c}-5.786 \mathrm{E}-02 \\
(-0.561)\end{array}$ \\
\hline MANUFACTURING & $\begin{array}{c}-0.216 \\
(-2.247)^{\star \star}\end{array}$ & $\begin{array}{c}-0.204 \\
(-2.091)^{\star \star}\end{array}$ & $\begin{array}{c}-0.255 \\
(2.620)^{\star \star \star}\end{array}$ & $\begin{array}{c}-7.639 \mathrm{E}-02 \\
(-1.354)\end{array}$ & $\begin{array}{c}-0.113 \\
(-2.016)^{\star *}\end{array}$ \\
\hline TRANSPORTATION, COMMUNICATIONS, OTHER PUBLIC UTILITIES & $\begin{array}{c}3.949 \mathrm{E}-02 \\
(0.308)\end{array}$ & $\begin{array}{c}7.668 \mathrm{E}-02 \\
(0.584)\end{array}$ & $\begin{array}{c}3.232 \mathrm{E}-02 \\
(0.247)\end{array}$ & $\begin{array}{c}6.777 \mathrm{E}-02 \\
(0.918)\end{array}$ & $\begin{array}{c}5.508 \mathrm{E}-02 \\
(0.748)\end{array}$ \\
\hline WHOLESALE AND RETAIL TRADE & $\begin{array}{c}-0.492 \\
(-5.089)^{\star \star \star}\end{array}$ & $\begin{array}{c}-0.480 \\
(-4.881)^{\star \star \star}\end{array}$ & $\begin{array}{c}-0.546 \\
(-5.604)^{\star \star \star}\end{array}$ & $\begin{array}{c}-0.290 \\
(-5.254)^{\star \star \star}\end{array}$ & $\begin{array}{c}-0.328 \\
(-6.030)^{\star \star \star}\end{array}$ \\
\hline FINANCE, INSURANCE, REAL ESTATE & $\begin{array}{c}-4.641 \mathrm{E}-02 \\
(-0.433)\end{array}$ & $\begin{array}{c}-2.794 \mathrm{E}-02 \\
(-0.255)\end{array}$ & $\begin{array}{c}-5.350 \mathrm{E}-02 \\
(-0.490)\end{array}$ & $\begin{array}{c}-1.903 E-02 \\
(-0.307)\end{array}$ & $\begin{array}{c}-1.271 \mathrm{E}-02 \\
(-0.205)\end{array}$ \\
\hline BUSINESS, REPAIR SERVICES & $\begin{array}{c}-7.932 \mathrm{E}-02 \\
(-0.575)\end{array}$ & $\begin{array}{c}-6.604 \mathrm{E}-02 \\
(-0.472)\end{array}$ & $\begin{array}{c}-9.933 \mathrm{E}-02 \\
(-0.708)\end{array}$ & $\begin{array}{c}-9.756 \mathrm{E}-02 \\
(-1.478)\end{array}$ & $\begin{array}{c}-0.122 \\
(-1.865)^{\star}\end{array}$ \\
\hline PERSONAL SERVICES & $\begin{array}{c}-0.554 \\
(-4.842)^{\star \star \star}\end{array}$ & $\begin{array}{c}-0.527 \\
(-4.493)^{\star \star \star}\end{array}$ & $\begin{array}{c}-0.665 \\
(-5.786)^{\star \star \star}\end{array}$ & $\begin{array}{c}-0.333 \\
(-4.285)^{\star \star \star}\end{array}$ & $\begin{array}{c}-0.416 \\
(-5.432)^{\star \star \star}\end{array}$ \\
\hline ENTERTAINMENT, RECREATION SERVICES & $\begin{array}{c}-0.631 \\
(-3.079)^{\star \star \star}\end{array}$ & $\begin{array}{l}-0.614634 \\
(-2.920)^{\star \star \star}\end{array}$ & $\begin{array}{c}-0.683 \\
(-3.258)^{\star \star \star}\end{array}$ & $\begin{array}{c}-9.919 \mathrm{E}-02 \\
(-0.927)\end{array}$ & $\begin{array}{c}-0.138 \\
(-1.295)\end{array}$ \\
\hline PROFESSIONAL, RELATED SERVICES & $\begin{array}{c}-0.207 \\
(-2.334)^{\star \star}\end{array}$ & $\begin{array}{c}-0.198 \\
(-2.199)^{\star \star}\end{array}$ & $\begin{array}{c}-0.243 \\
(-2.691)^{\star \star \star}\end{array}$ & $\begin{array}{c}-0.148 \\
(-2.840)^{\star \star \star}\end{array}$ & $\begin{array}{c}-0.178 \\
(-3.448)^{\star \star \star}\end{array}$ \\
\hline NORTHEAST & $\begin{array}{c}9.368 \mathrm{E}-02 \\
(1.528)\end{array}$ & $\begin{array}{c}9.895 \mathrm{E}-02 \\
(1.583)\end{array}$ & $\begin{array}{c}7.792 \mathrm{E}-02 \\
(1.241)\end{array}$ & $\begin{array}{l}8.860 \mathrm{E}-02 \\
(2.676)^{\star \star *}\end{array}$ & $\begin{array}{l}7.704 \mathrm{E}-02 \\
(2.328)^{\star \star \star}\end{array}$ \\
\hline NORTH CENTRAL & $\begin{array}{c}1.570 \mathrm{E}-02 \\
(0.247)\end{array}$ & $\begin{array}{c}7.298 \mathrm{E}-03 \\
(0.113)\end{array}$ & $\begin{array}{c}-1.202 \mathrm{E}-02 \\
(-0.185)\end{array}$ & $\begin{array}{c}-2.280 \mathrm{E}-02 \\
(-0.694)\end{array}$ & $\begin{array}{c}-4.023 \mathrm{E}-02 \\
(-1.229)\end{array}$ \\
\hline SOUTH & $\begin{array}{c}-7.454 \mathrm{E}-02 \\
(-1.394)\end{array}$ & $\begin{array}{c}-7.820 \mathrm{E}-02 \\
(-1.432)\end{array}$ & $\begin{array}{c}-6.201 \mathrm{E}-02 \\
(-1.133)\end{array}$ & $\begin{array}{c}-8.509 E-02 \\
(-2.799)^{\star \star}\end{array}$ & $\begin{array}{c}-7.644 \mathrm{E}-02 \\
(-2.519)^{\star *}\end{array}$ \\
\hline $\mathrm{R}^{2}$ & 0.420 & 0.400 & 0.395 & 0.242 & 0.244 \\
\hline $\operatorname{adj} . R^{2}$ & 0.399 & 0.378 & 0.373 & 0.237 & 0.239 \\
\hline nobs. & 516 & 516 & 516 & 2579 & 2579 \\
\hline rate of return to experience at 10 years & 2.722E-02 & 2.903E-02 & $1.908 \mathrm{E}-02$ & 2.044E-02 & 1.729E-02 \\
\hline
\end{tabular}

note: ACTUAL and PREDICTED WORK EXPERIENCE are constructed from total annual work hours as reported in the family files and POTENTIAL WORK EXPERIENCE=age-schooling. 